
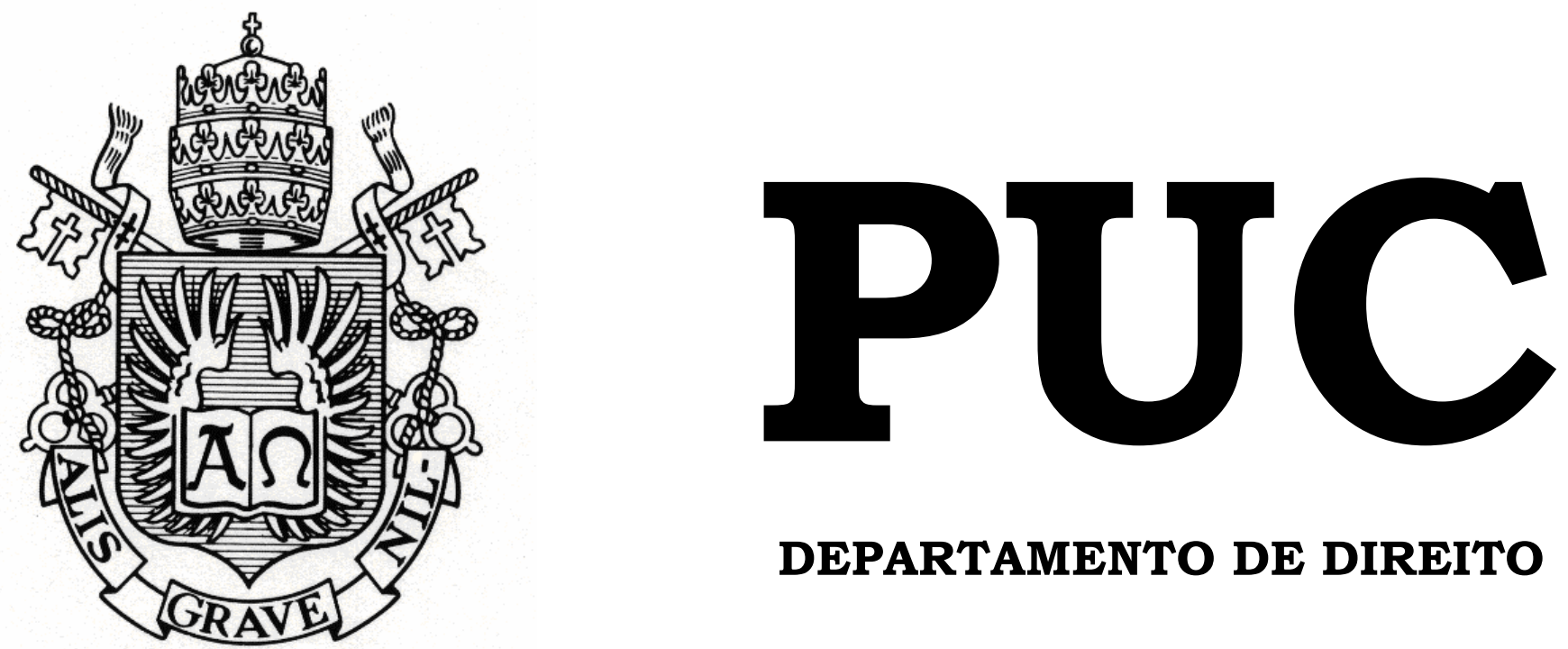

DEPARTAMENTO DE DIREITO

\title{
O ICMS ECOLÓGICO
}

por

PRISCILLA BONAPARTE

ORIENTADORA: Danielle Moreira

2005.1

PONTIFÍCIA UNIVERSIDADE CATÓLICA DO RIO DE JANEIRO

RUA MARQUÊS DE SÃO VICENTE, 225 - CEP 22453-900

RIO DE JANEIRO - BRASIL 


\title{
O ICMS ECOLÓGICO
}

\author{
por
}

\section{PRISCILLA BONAPARTE}

Monografia apresentada ao

Departamento de Direito da Pontificia Universidade Católica do Rio de Janeiro (PUC-Rio) para a obtenção do Título de Bacharel em Direito.

Orientadora: Danielle Moreira

2005.1 
Agradeço

À querida orientadora Danielle Moreira, pelo exemplo de pessoa e profissional batalhadora e dedicada.

Ao Professor Fernando Walcacer, não menos querido, por todas as oportunidades no NIMA, conversas e risadas.

Às maravilhosas amigas Adriana Bocaiuva, Cristina Leme Lopes e Bianca Prado, pela troca de preciosas informações, por todas as fofocas e pela amizade em vários momentos importantes. 


\section{Resumo}

O desenvolvimento sustentável se tornou o principal objetivo da gestão ambiental. A produção econômica sempre gera externalidades, podendo ser positivas (gerando benefícios sociais) ou negativas (gerando perdas à sociedade). Como solução para a internalização dessas externalidades, mais especificamente as negativas, apresentam-se instrumentos econômicos, dentre os quais a tributação ambiental.

A tributação ambiental tem o objetivo de induzir comportamentos ambientalmente sustentáveis por parte dos agentes econômicos. No Brasil, a experiência mais importante no campo da tributação ambiental é, sem dúvida, a implantação, por alguns Estados, do chamado ICMS Ecológico.

O ICMS Ecológico, criado pioneiramente no Paraná, trata de critérios ambientais para o repasse de recursos financeiros do ICMS a que os Municípios têm direito constitucionalmente. Neste trabalho, analisa-se, através do exame da legislação dos Estados e de algumas experiências, a contribuição do ICMS Ecológico à preservação do meio ambiente.

Palavras-chave: ICMS ecológico; meio ambiente; desenvolvimento sustentável; tributação ambiental; preservação. 


\section{Sumário}

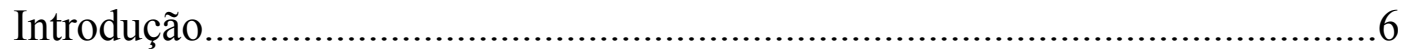

Capítulo 1. Direito Ambiental e Direito Econômico...............................................8

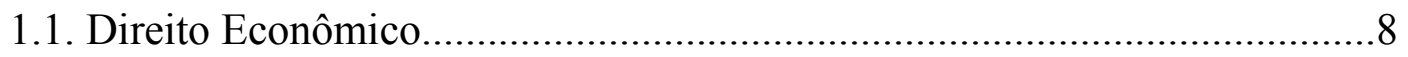

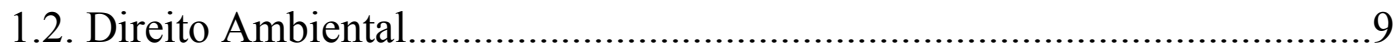

1.3. Princípios Norteadores do Direito Econômico e do Direito Ambiental....12

1.3.1. Princípio da Participação.............................................................12

1.3.2. Princípio da Prevenção...............................................................14

1.3.3. Princípio da Precaução...................................................................15

1.3.4. Princípio do Desenvolvimento Sustentável...................................17

1.3.4.1. Crescimento Sustentável x Desenvolvimento

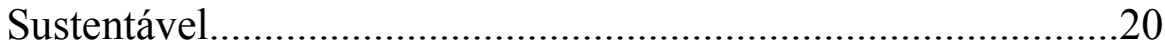

1.3.4.2. O Desenvolvimento Sustentável e a CF de 1988............21

1.3.5. Princípio do Poluidor Pagador........................................................21

1.3.5.1. Externalidades da Produção Econômica e Internalização dos Custos Ambientais..........................................23

1.3.6. Princípio do Protetor Recebedor ou do

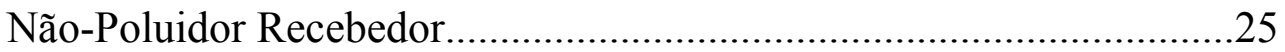

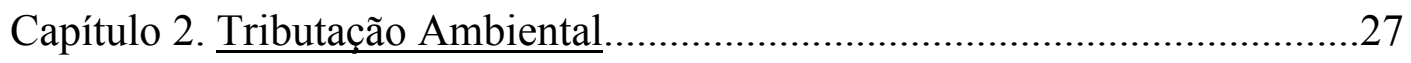

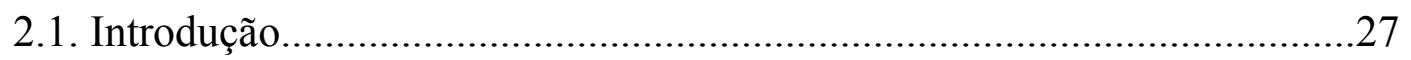

2.2. Finalidade Extrafiscal dos Tributos Ambientais e as

Formas de sua Implementação.....................................................................28

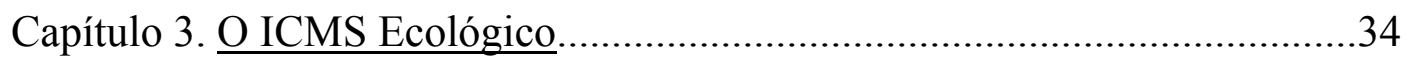

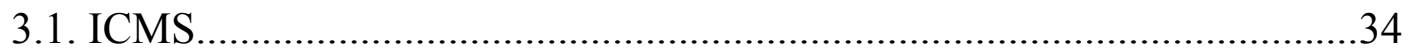

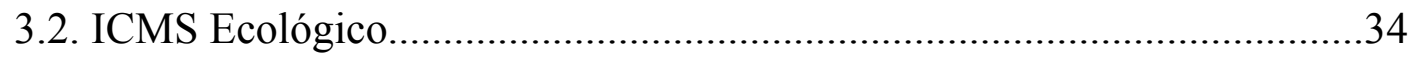

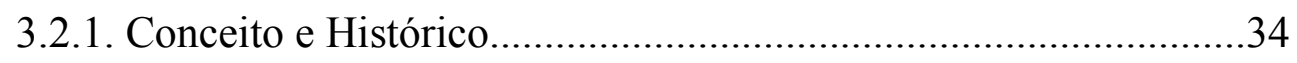

3.2.2. Fundamentação Constitucional........................................................

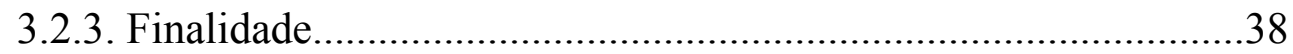


3.2.4. Legislação Estadual: critérios adotados....................................39

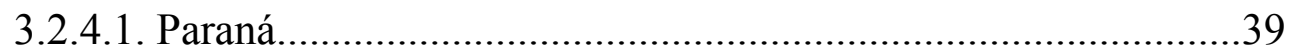

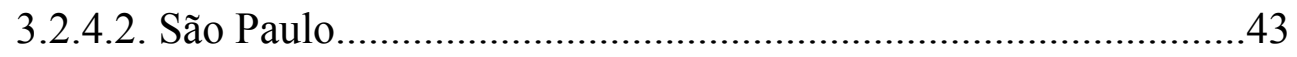

3.2.4.3. Minas Gerais.......................................................................44

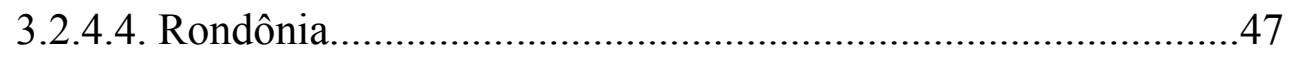

3.2.4.5. Amapá ..............................................................................48

3.2.4.6. Rio Grande do Sul...............................................................49

3.2.4.7. Mato Grosso do Sul..............................................................49

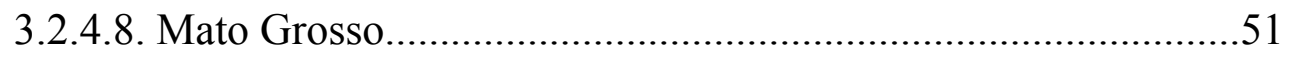

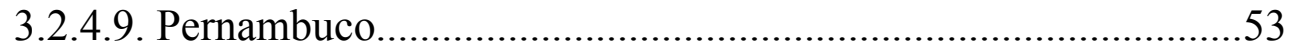

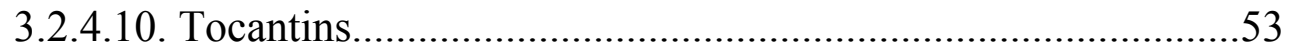

3.2.5. Alguns resultados obtidos com a experiência

do ICMS Ecológico............................................................................57

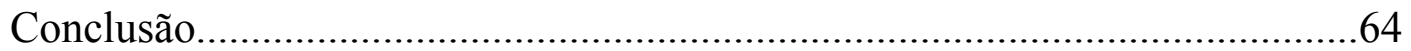

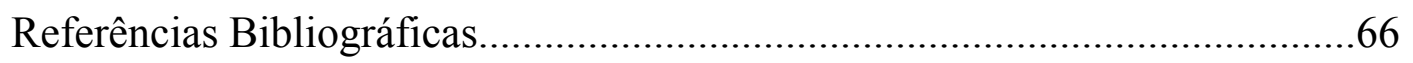




\section{Introdução}

A principal tarefa da gestão ambiental deixou de ser o combate ao desenvolvimento selvagem, e tornou-se o fomento ao desenvolvimento sustentável, que considera relações econômicas ao longo do tempo.

No campo das atividades econômicas, sabe-se que elas quase sempre geram repercussões ambientais, na medida em que se utilizam do seu poder transformador sobre os recursos naturais.

Nesse contexto, os tradicionais instrumentos de gestão ambiental baseados no comando e controle, na fiscalização e licenciamento ambientais, são insuficientes para induzir novos comportamentos nos agentes econômicos. Eles precisam ser combinados com instrumentos econômicos, para induzir os empreendedores a adotarem práticas ambientalmente sustentáveis.

Neste trabalho, pretende-se demonstrar a importância de uma abordagem interdisciplinar da utilização dos instrumentos econômicos, para atingir o objetivo precípuo do Direito Ambiental, que é a proteção do meio ambiente através da prevenção dos danos.

No primeiro capítulo, tem-se uma descrição de princípios comuns ao Direito Econômico e ao Direito Ambiental, com especial destaque aos Princípios do Desenvolvimento Sustentável e do Poluidor Pagador. Aborda-se, também, a questão das externalidades da produção econômica e a necessidade de internalização das mesmas.

No segundo capítulo, é analisada a tributação ambiental, como forma de internalização das externalidades negativas. Além disso, este capítulo tratará também do caráter extrafiscal da tributação ambiental e das formas como ela pode ser implementada.

No Brasil, a experiência mais importante no campo da tributação ambiental é, sem dúvida, a implantação, por alguns Estados, do chamado 
ICMS Ecológico. Portanto, no terceiro capítulo, o foco passa ao tema principal deste trabalho, o ICMS Ecológico, como instrumento financeiro de proteção ao meio ambiente. Passa-se a descrever o contexto em que ele surge, as diversas formas como foi adotado pelos Estados brasileiros, e os benefícios auferidos com a sua implementação. 


\section{Direito Ambiental e Direito Econômico}

\subsection{Direito Econômico}

Nas palavras de Washington Peluso Albino de Souza:

"Direito Econômico é o ramo do Direito que tem por objeto a 'jurisdicização', ou seja, o tratamento jurídico da política econômica e, por sujeito, o agente que dela participe. Como tal, é o conjunto de normas de conteúdo econômico que assegura a defesa dos interesses individuais e coletivos, de acordo com a ideologia adotada na ordem jurídica. Para tanto, utiliza-se do "princípio da economicidade'."1

O princípio da economicidade traduz a idéia de justiça. Para Ricardo Lobo Torres, implica "na eficiência na gestão financeira e na execução orçamentária, consubstanciada na minimização de custos e gastos públicos e na maximização da receita e da arrecadação". Por fim, conclui que é, "sobretudo, a justa adequação e equilíbrio entre as duas vertentes das finanças públicas."

O direito econômico é um instrumento utilizado pela política econômica. Porém, não se esgota nisso o seu relacionamento com a economia. $\mathrm{O}$ direito econômico também orienta a política econômica, sendo o fundamento desta, o ponto de partida para o seu desenvolvimento. "O direito é concebido na sua relação com a economia como um instrumento de sua efetivação e, ao mesmo tempo, como meio de direcionamento da mesma."4

\footnotetext{
${ }^{1}$ SOUZA, Washington Peluso Albino de. Primeiras Linhas de Direito Econômico. 4 a ed. São Paulo: LTR, 1999. p. 27. apud MODÉ, Fernando Magalhães. Tributação Ambiental - a função do tributo na proteção do meio ambiente. Curitiba: Juruá, 2003. p. 42-43.

${ }^{2}$ TORRES, Ricardo Lobo. O Tribunal de Contas e o controle da legalidade, economicidade e legitimidade. Rio de Janeiro, Revista do TCE/RJ, nº 22, jul/1991, pp. 37/44.

${ }^{3}$ DERANI, Cristiane. Direito Ambiental Econômico. São Paulo: Max Limonad, 1997. p. 57-58.

${ }^{4}$ DERANI, Cristiane. Direito Ambiental Econômico. São Paulo: Max Limonad, 1997. p. 64.
} 
Ao visar à manutenção do sistema produtivo, o direito econômico trabalha, necessariamente, com institutos de implementação do desenvolvimento. É, então, o direito do desenvolvimento econômico. ${ }^{5}$

Cristiane Derani demonstra a relação entre políticas econômicas e ambientais, entendendo que:

"São indissociáveis os fundamentos econômicos de uma política ambiental conseqüente e exeqüível. E uma política econômica conseqüente não ignora a necessidade de uma política de proteção dos recursos naturais. Para isto, a economia deve voltar aos seus pressupostos sociais e abandonar qualquer pretensão por uma ciência exata. Pois, o que está em jogo não é só a otimização do uso privado de recursos, mas as 'externalidades' decorrentes e o modo de como esses recursos são apropriados. A economia política deve distender-se para uma política econômica - que na verdade deve ser denominada de modo mais abrangente como política social. Através de uma política econômica, pode-se empreender macro-planejamentos que coordenem interesses privados e coletivos, evitando que a realização de um seja a negação do outro, reinserindo a produção dentro de uma finalidade de constituição de riqueza social, voltando-se à melhoria da vida em sociedade."

\subsection{Direito Ambiental}

O conceito de meio ambiente é dado, no ordenamento jurídico nacional, pela Lei 6.938/81, artigo 30, I, "meio ambiente: o conjunto de condições, leis, influências e interações de ordem física, química e biológica, que permite, abriga e rege a vida, em todas as suas formas". É considerado como "um patrimônio público a ser necessariamente assegurado e protegido, tendo em vista o uso coletivo" (artigo $\left.2^{\circ}, \mathrm{I}\right)$.

Assim, vê-se que a conceituação legal é bastante ampla, não limitando a relação do ambiente ao homem, mas sim a todas as formas de vida. ${ }^{7}$

\footnotetext{
${ }^{5}$ DERANI, Cristiane. Direito Ambiental Econômico. São Paulo: Max Limonad, 1997. p. 67.

${ }^{6}$ DERANI, Cristiane. Direito Ambiental Econômico. São Paulo: Max Limonad, 1997. p. 68.

${ }^{7}$ MUKAI, Toshio. Direito Ambiental Sistematizado. $4^{\mathrm{a}}$ ed. Rio de Janeiro: Forense Universitária, 2002. P. 4.
} 


\section{Nas lições de Cristiane Derani,}

"meio ambiente deixa-se conceituar como um espaço onde se encontram os recursos naturais, inclusive aqueles já reproduzidos (transformados) ou degenerados (poluídos) como no caso do meio ambiente urbano. Importante ressaltar que este conceito de meio ambiente não se reduz a ar, água, terra, mas deve ser definido como o conjunto das condições de existência humana, que integra e influencia o relacionamento entre os homens, sua saúde e seu desenvolvimento." 8

Para o Professor Paulo Affonso Leme Machado,

"O Direito Ambiental é um Direito sistematizador, que faz a articulação da legislação, da doutrina e da jurisprudência concernentes aos elementos que integram o ambiente. Procura evitar o isolamento dos temas ambientais e sua abordagem antagônica. Não se trata mais de construir um Direito das águas, um Direito da atmosfera, um Direito do solo, um Direito florestal, um Direito da fauna ou um Direito da biodiversidade. O Direito Ambiental não ignora o que cada matéria tem de específico, mas busca interligar estes temas com a argamassa da identidade dos instrumentos jurídicos de prevenção e de reparação, de informação, de monitoramento e de participação."

\section{O direito econômico e o direito ambiental comportam, essencialmente,} as mesmas preocupações, quais sejam: buscar a melhoria do bem-estar das pessoas e a estabilidade do processo produtivo. Conforme esse entendimento,

"a despeito da existência de dois fundamentos orientando a formação do direito econômico e direito ambiental, ambos almejam, em suma, atender àquele conjunto de atividades e estados humanos substantivados na expressão qualidade de vida. Tal expressão traz o condão de traduzir todo o necessário aparato interno e externo ao homem, dando-lhe condições de desenvolver suas potencialidades como indivíduo e como parte fundamental de uma sociedade." 10

\footnotetext{
${ }^{8}$ DERANI, Cristiane. Direito Ambiental Econômico. São Paulo: Max Limonad, 1997. p. 70-71.

9 MACHADO, Paulo Affonso Leme. Direito Ambiental Brasileiro. $11^{\mathrm{a}}$ ed. São Paulo: Malheiros, 2003. P. 139-140.

${ }^{10}$ DERANI, Cristiane. Direito Ambiental Econômico. São Paulo: Max Limonad, 1997. p. 76-77.
} 
O direito econômico visa a dar cumprimento aos preceitos da ordem econômica constitucional. Ou seja, a estrutura normativa construída sob a designação de direito econômico tem por fim assegurar a todos existência digna, perseguindo a realização da justiça social (CF, artigo 170, caput).

Já o direito ambiental se baseia no direito ao meio ambiente ecologicamente equilibrado, bem de uso comum do povo e essencial à sadia qualidade de vida, passível de fruição por toda a coletividade (CF, artigo 225, caput). Com base neste direito fundamental, desdobram-se as demais normas pertencentes ao ramo do chamado direito ambiental.

Ainda segundo Cristiane Derani:

“A Constituição Federal Brasileira contém este caráter integrador da ordem econômica com a ordem ambiental, unidas pelo elo comum da finalidade de melhoria da qualidade de vida. O direito de todos a um meio ambiente ecologicamente equilibrado pode ser caracterizado como um direito fundamental, gozando do mesmo 'status' daqueles descritos no artigo quinto desta carta. Este bem jurídico, o meio ambiente ecologicamente equilibrado, é um pressuposto para a concretização da qualidade de vida, a qual afirma-se, por sua vez, como a finalidade máxima das normas do capítulo do meio ambiente. Este capítulo revela-se em normas destinadas a reformular a ação do homem sobre o seu meio."11

O direito ambiental é um direito transversal, uma vez que perpassa todo o ordenamento jurídico, não lhe cabendo uma delimitação rígida e estática. Por ter um caráter teleológico, o direito ambiental pode conter normas que são direcionadoras de regras originariamente pertencentes a outros ramos do Direito. $^{12}$

\footnotetext{
${ }^{11}$ DERANI, Cristiane. Direito Ambiental Econômico. São Paulo: Max Limonad, 1997. p. 78-79.

${ }^{12}$ DERANI, Cristiane. Direito Ambiental Econômico. São Paulo: Max Limonad, 1997. p. 84.
} 


\subsection{Princípios Norteadores do Direito Econômico e do Direito Ambiental}

A doutrina identifica princípios que são comuns a esses dois ramos do Direito. Isso se deve ao fato de ambos terem como objetivo mediato o bemestar social e a sadia qualidade de vida. Neste trabalho, serão abordados os seguintes: princípio da participação, princípio da prevenção, princípio da precaução, princípio do desenvolvimento sustentável, princípio do poluidor pagador, e princípio do protetor recebedor (ou princípio do não-poluidor recebedor).

\subsubsection{Princípio da Participação}

A Declaração do Rio de Janeiro, da Conferência das Nações Unidas para o Meio Ambiente e o Desenvolvimento, de 1992, em seu artigo 10 diz: "O melhor modo de tratar as questões do meio ambiente é assegurando a participação de todos os cidadãos interessados, no nível pertinente.”

A participação popular tem, como fundamento genérico o $\operatorname{artigo~} 1^{\circ}$, da Constituição Federal de 1988, e, como fundamento específico em matéria de meio ambiente, o artigo 225, caput. Trata-se, portanto, de decorrência necessária do direito de todos ao meio ambiente ecologicamente equilibrado e do regime jurídico do ambiente como bem de uso comum do povo. ${ }^{13}$

Paulo Affonso Leme Machado compreende o princípio da participação de quatro formas: participação na formação das decisões administrativas, participação nos recursos administrativos e nos julgamentos administrativos, participação legislativa direta (através da instituição do plebiscito ou do referendo ambiental) e a participação nas ações judiciais ambientais. ${ }^{14}$

\footnotetext{
${ }^{13}$ MIRRA, Álvaro Luiz Valery. Princípios Fundamentais do Direito Ambiental. Revista de Direito Ambiental. São Paulo, n. 2. p. 50 - 66.

${ }^{14}$ MACHADO, Paulo Affonso Leme. Direito Ambiental Brasileiro. $11^{\mathrm{a}}$ ed. São Paulo: Malheiros, 2003. P. 83-85.
} 
Já o autor Paulo de Bessa Antunes chama o princípio da participação de princípio democrático (incluindo neste o princípio da informação, tratado separadamente por Paulo Affonso Leme Machado), significando:

"o direito que os cidadãos têm de receber informações sobre as diversas intervenções que atinjam o meio ambiente e, mais, por força do mesmo princípio, devem ser assegurados a todos os cidadãos os mecanismos judiciais, legislativos e administrativos capazes de tornarem tal princípio efetivo." 15

Como corolário do princípio da participação, encontra-se o princípio da cooperação que, segundo Cristiane Derani, é o princípio através do qual se consolida uma divisão de funções dentro da ordem econômica, que tem por fundamento as relações de mercado, reportando ao Estado e aos cidadãos a divisão dos custos decorrentes da implementação de uma política preventiva de proteção ambiental. $^{16}$

\footnotetext{
${ }^{15}$ ANTUNES, Paulo de Bessa. Direito Ambiental. Rio de Janeiro: Lúmen Júris, 2000. p. 28.

16 “O princípio da cooperação informa uma atuação conjunta do Estado e sociedade, na escolha de prioridades e nos processos decisórios. Ele está na base dos instrumentos normativos criados com objetivos de aumento da informação e de ampliação de participação nos processos de decisão da política ambiental, bem como de estabilidade no relacionamento entre liberdade individual e necessidade social. Uma ampla informação e esclarecimento dos cidadãos bem como um trabalho conjunto entre organizações ambientalistas, sindicatos, indústria, comércio e agricultura é fundamental para o desenvolvimento de políticas ambientais efetivas e para a otimização da concretização de normas voltadas à proteção do meio ambiente.

Este princípio suporta também normas de incentivo à ciência e tecnologia a serviço da proteção ambiental, normas que abrem espaço para a cooperação entre os Estados e Municípios, como também para uma cooperação de âmbito internacional, onde é fundamental um trabalho conjunto que supere fronteiras.

Pode-se dizer que o princípio da cooperação é resultado de uma divisão de funções dentro da ordem econômica fundada nas relações de mercado. Sua concretização, como princípio do direito ambiental e do direito econômico simultaneamente, se dá, por exemplo, quando se determina a divisão dos custos de uma política preventiva de proteção ambiental, implicando uma negociação constante entre as atividades do Estado e do cidadão." (DERANI, Cristiane. Direito Ambiental Econômico. São Paulo: Max Limonad, 1997. p. 157-158)
} 


\subsubsection{Princípio da Prevenção}

Para Álvaro Mirra ${ }^{17}$, esse princípio decorre da constatação de que as agressões ao meio ambiente são, em regra, de difícil ou impossível reparação. Isso significa que, quando da ocorrência de um dano ambiental, nem sempre poderá ser feita sua reparação e, certamente, nos casos em que isso seja possível, os custos serão bastante altos. Portanto, é necessária uma atuação preventiva, visando a evitar o dano.

Além disso, o princípio da prevenção está relacionado à exigência prevista na Constituição Federal de que as gerações atuais transmitam às futuras o patrimônio ambiental.

A Lei da Política Nacional do Meio Ambiente (Lei 6.938/81) inseriu como um dos seus objetivos a compatibilização do desenvolvimento econômico-social com a preservação da qualidade do meio ambiente e do equilíbrio ecológico e a preservação dos recursos ambientais, com vistas à sua utilização racional e disponibilidade permanente (artigo $4^{\circ}$, I e VI). Entre os instrumentos da Política Nacional do Meio Ambiente colocou-se a "avaliação dos impactos ambientais" (artigo $9^{\circ}$, III).

No artigo $2^{\circ}$, dispõe que a Política Nacional do Meio Ambiente tem por objetivos a preservação, melhoria e recuperação da qualidade ambiental, atendidos, dentre outros princípios, os seguintes: I - ação governamental na manutenção do equilíbrio ecológico, considerando o meio ambiente como um patrimônio público a ser necessariamente assegurado e protegido, tendo em vista o uso coletivo; IV - proteção dos ecossistemas, com a preservação de áreas representativas; IX - proteção de áreas ameaçadas de degradação. Assim, encontra-se positivado no Direito brasileiro o princípio da prevenção.

\footnotetext{
${ }^{17}$ MIRRA, Álvaro Luiz Valery. Principios Fundamentais do Direito Ambiental. Revista de Direito Ambiental. São Paulo, n. 2. p. $50-66$.
} 
A Convenção da Diversidade Biológica diz, em seu Preâmbulo, que "é vital prever, prevenir e combater na origem as causas da sensível redução ou perda da diversidade biológica".

Paulo Affonso Leme Machado entende que sem informação organizada e sem pesquisa não há prevenção. Por isso, divide "em cinco itens a aplicação do princípio da prevenção: $1^{\circ}$ ) identificação e inventário das espécies animais e vegetais de um território, quanto à conservação da natureza e identificação das fontes contaminantes das águas e do mar, quanto ao controle da poluição; $2^{\circ}$ ) identificação e inventário dos ecossistemas, com a elaboração de um mapa ecológico; $3^{\circ}$ ) planejamentos ambiental e econômico integrados; $4^{\circ}$ ) ordenamento territorial ambiental para a valorização das áreas de acordo com a sua aptidão; e $5^{\circ}$ ) Estudo de Impacto Ambiental." 18

Ainda na opinião do Professor Paulo Affonso, aplica-se o princípio da prevenção quando o risco é certo ${ }^{19}$. Porém, “a prevenção não é estática; e, assim, tem-se que atualizar e fazer reavaliações, para poder influenciar a formulação das novas políticas ambientais, das ações dos empreendedores, e das atividades da Administração Pública, dos legisladores e do Judiciário". ${ }^{20}$

\subsubsection{Princípio da Precaução}

Conforme o Professor Paulo Affonso Leme $\mathrm{Machado}^{21}$, a implementação do princípio da precaução não tem por finalidade imobilizar as atividades humanas, mas sim, visa à durabilidade da sadia qualidade de vida das gerações humanas e à continuidade da natureza existente no planeta. A

\footnotetext{
${ }^{18}$ MACHADO, Paulo Affonso Leme. Estudos de Direito Ambiental, p. 36. apud MACHADO, Paulo Affonso Leme. Direito Ambiental Brasileiro. $11^{\mathrm{a}}$ ed. São Paulo: Malheiros, 2003. P.73.

${ }^{19}$ Palestra sobre a Lei 11.105/05, proferida na PUC-Rio no dia 19.05.2005.

${ }^{20}$ MACHADO, Paulo Affonso Leme. Direito Ambiental Brasileiro. $11^{\mathrm{a}}$ ed. São Paulo: Malheiros, 2003. P.74.

${ }^{21}$ MACHADO, Paulo Affonso Leme. Direito Ambiental Brasileiro. $11^{\mathrm{a}}$ ed. São Paulo: Malheiros, 2003. P.56.
} 
precaução deve ser visualizada não só em relação às gerações presentes, como também em relação ao meio ambiente das gerações futuras.

Para Cristiane Derani,

"Precaução é cuidado (in dubio pro securitate). O princípio da precaução está ligado aos conceitos de afastamento de perigo e segurança das gerações futuras, como também de sustentabilidade ambiental das atividades humanas. Este princípio é a tradução da busca da proteção da existência humana, seja pela proteção de seu ambiente como pelo asseguramento da integridade da vida humana. A partir desta premissa, deve-se também considerar não só o risco iminente de uma determinada atividade como também os riscos futuros decorrentes de empreendimentos humanos, os quais nossa compreensão e o atual estágio de desenvolvimento da ciência jamais conseguem captar em toda densidade." 22

De acordo com o Princípio 15 da Declaração do Rio de Janeiro ${ }^{23}$ :

"De modo a proteger o meio ambiente, o princípio da precaução deve ser amplamente observado pelos Estados, de acordo com suas capacidades. Quando houver ameaça de danos sérios ou irreversíveis, a ausência de absoluta certeza científica não deve ser utilizada como razão para postergar medidas eficazes e economicamente viáveis para prevenir a degradação ambiental."

O princípio da precaução tem um significado mais específico que o da prevenção, "querendo fornecer indicação sobre as decisões a tomar nos casos em que os efeitos sobre o meio ambiente de uma determinada atividade não sejam ainda plenamente conhecidos no plano científico." 24

O Brasil assinou, ratificou e promulgou duas Convenções internacionais que inseriram o princípio da precaução: a Convenção da Diversidade

\footnotetext{
${ }^{22}$ DERANI, Cristiane. Direito Ambiental Econômico. São Paulo: Max Limonad, 1997. p. 167.

${ }^{23}$ A Conferência das Nações Unidas para o Meio Ambiente e o Desenvolvimento, reunida no Rio de Janeiro em 1992, votou, por unanimidade, a chamada "Declaração do Rio de Janeiro", com 27 princípios.

${ }^{24}$ Sul principio precauzionale nell Diritto Internazionale dell' Ambiente, Rivista de Diritto Internazionale LXXV/699-705, fasc. 3, Milão, Giuffrè Editore, 1992. apud MACHADO, Paulo Affonso Leme. Direito Ambiental Brasileiro. $11^{\mathrm{a}}$ ed. São Paulo: Malheiros, 2003. P.58.
} 
Biológica $^{25}$ e a Convenção-Quadro das Nações Unidas sobre a Mudança Climática $^{26}$.

A Convenção da Diversidade Biológica diz, entre os considerandos de seu Preâmbulo: “Observando também que, quando exista ameaça de sensível redução ou perda da diversidade biológica, a falta de plena certeza científica não deve ser usada como razão para postergar medidas para evitar ou minimizar essa ameaça...". ${ }^{27}$

A Convenção-Quadro das Nações Unidas sobre a Mudança Climática diz em seu artigo $3^{\circ}$ :

"Princípios - 3. As Partes devem adotar medidas de precaução para prever, evitar ou minimizar as causas da mudança do clima e mitigar seus efeitos negativos. Quando surgirem ameaças de danos sérios ou irreversíveis, a falta de plena certeza científica não deve ser usada como razão para postergar essas medidas, levando em conta que as políticas e medidas adotadas para enfrentar a mudança do clima devem ser eficazes em função dos custos, de modo a assegurar benefícios mundiais ao menor custo possível". ${ }^{28}$

O que distingue o princípio da prevenção do princípio da precaução é que, no primeiro, em caso de certeza do dano ambiental, este deve ser prevenido. Se houver dúvida ou incerteza, expressa com argumentos razoáveis, quanto à existência de dano, também se deve agir prevenindo, sendo esta a grande inovação do princípio da precaução.

\subsubsection{Princípio do Desenvolvimento Sustentável}

“Quinto país em extensão territorial, o Brasil tem 1,7\% da superfície da terra (5,7\% das áreas emersas) e 47,3\% da América do Sul. Sua população é a sexta do mundo, com mais de 160 milhões de habitantes. Some-se a esses

\footnotetext{
${ }^{25}$ Assinada no Rio de Janeiro em 5 de junho de 1992, ratificada pelo Congresso Nacional pelo Decreto Legislativo 2, de 3.2.1994, tendo entrado em vigor para o Brasil em 29 de maio de 1994.

${ }^{26}$ Assinada em Nova York em 9 de maio de 1992, ratificada pelo Congresso Nacional pelo Decreto Legislativo 1, de 3.2.1994, passou a vigorar para o Brasil em 29 de maio de 1994.

${ }^{27}$ Decreto 2.519, de 16.3.1998, promulgando a Convenção (DOU 17.3.1998).

${ }^{28}$ Decreto 2.652, de 1.7.1998, promulgando a Convenção (DOU 2.7.1998).
} 
dados superlativos a riqueza do seu patrimônio natural e configurado está um país que, compreensivelmente, ocupa posição central nas discussões sobre a sustentabilidade do planeta." 29

A idéia básica é a de incluir a proteção do meio ambiente, não como um aspecto isolado, mas como parte integrante do processo global de desenvolvimento dos países. Como conseqüência disso, no entendimento de Álvaro Mirra, deve-se situar a defesa do meio ambiente no mesmo plano, em importância, de outros valores econômicos e sociais protegidos pela ordem jurídica. ${ }^{30}$

Na concepção de José Marcos Domingues de Oliveira,

"o desenvolvimento sustentável, que se baseia num princípio ético, isto é, o desenvolvimento atual não deve prejudicar as gerações futuras, consiste no progresso da atividade econômica compatível com a utilização racional dos recursos ambientais. Representa a rejeição do desperdício, da ineficiência e do desprezo por esses recursos." 31

O Desenvolvimento Sustentável é um novo modelo de desenvolvimento, em processo de construção, que surgiu no final do século 20 como resposta ao esgotamento de um modelo que o relatório brasileiro para a Rio-92 descreve como 'ecologicamente predatório, socialmente perverso e politicamente injusto' ${ }^{32}$

$\mathrm{Na}$ Declaração do Rio de Janeiro encontra-se a referência expressa ao princípio do desenvolvimento sustentável no enunciado de 12 de seus 25 princípios. O conceito de desenvolvimento sustentável pode ser extraído do enunciado do Princípio 3, segundo o qual "o direito ao desenvolvimento deve

\footnotetext{
${ }^{29}$ BENJAMIN, Antônio Herman V. Introdução ao Direito Ambiental Brasileiro. p. 11. in SOARES JÚNIOR, Jarbas; GALVÃO, Fernando (coords.). Direito Ambiental na Visão da Magistratura e do Ministério Público. Minas Gerais: Del Rey, 2003.

${ }^{30}$ MIRRA, Álvaro Luiz Valery. Princípios Fundamentais do Direito Ambiental. Revista de Direito Ambiental. São Paulo, n. 2. p. 50 - 66.

${ }^{31}$ OLIVEIRA, José Marcos Domingues de. Direito Tributário e Meio Ambiente: Proporcionalidade, Tipicidade Aberta e Afetação da Receita. $2^{\mathrm{a}}$ ed. Rio de Janeiro: Renovar, 1999. p. 18-19.

${ }_{32}$ MOUSINHO, Patrícia. Glossário. p. 333-367. in TRIGUEIRO, André (coord.). Meio Ambiente no Século 21: 21 especialistas falam da questão ambiental nas suas áreas de conhecimento. $2^{\mathrm{a}}$ ed. Rio de Janeiro: Sextante, 2003.
} 
ser exercido, de modo a permitir que sejam atendidas eqüitativamente as necessidades de desenvolvimento e ambientais de gerações presentes e futuras".

De acordo com o Relatório Brundtland ${ }^{33}$, desenvolvimento sustentável é “o desenvolvimento que atende às necessidades do presente, sem comprometer a capacidade de as futuras gerações atenderem às próprias necessidades".

Assim, o desenvolvimento sustentável requer um horizonte de planejamento que vai além das necessidades e aspirações das populações atuais e exige, de imediato, a integração das questões ambientais, sociais e econômicas. Se, inicialmente, o desenvolvimento sustentável pretendia ser abrangente ao englobar não apenas aspectos econômicos, mas também sociais e ambientais, hoje esta perspectiva é bastante mais ampla, e a noção de sustentabilidade adotada pela Agenda 21 Brasileira incorpora as dimensões ecológica, ambiental, social, política, econômica, demográfica, cultural, institucional e espacial. $^{34}$

Para Cristiane Derani, "não há verdadeiro progresso com deterioração da qualidade de vida, e será ilusório qualquer desenvolvimento à custa da degradação ecológica." 35

\footnotetext{
${ }^{33}$ Relatório elaborado por uma comissão formada no âmbito do PNUMA (Programa das Nações Unidas para o Meio Ambiente) por decisão tomada na Assembléia Geral da ONU em 1985 com o objetivo de esboçar políticas relativas ao meio ambiente até o ano 2000 e para mais além. Essa comissão denominou-se Comissão Mundial sobre o Meio Ambiente e Desenvolvimento, tendo sido presidida pela então Primeira-Ministra da Noruega, Gro Harlem Brundtland, a qual em 1987 apresentou à Assembléia Geral da ONU um relatório consistente em uma série de estratégias para o equacionamento do desenvolvimento sustentável. No Brasil, o Relatório Brundtland foi publicado pela Comissão Mundial sobre o Meio Ambiente e Desenvolvimento, Fundação Getúlio Vargas. Nosso futuro comum, $2^{\mathrm{a}}$ ed. Rio de Janeiro, 1991.

${ }_{34}$ MOUSINHO, Patrícia. Glossário. p. 333-367. in TRIGUEIRO, André (coord.). Meio Ambiente no Século 21: 21 especialistas falam da questão ambiental nas suas áreas de conhecimento. $2^{\mathrm{a}}$ ed. Rio de Janeiro: Sextante, 2003.

${ }^{35}$ DERANI, Cristiane. Direito Ambiental Econômico. São Paulo: Max Limonad, 1997. p. 118.
} 


\subsubsection{Crescimento Sustentável x Desenvolvimento Sustentável}

Cristiane Derani ${ }^{36}$ explica muito bem a relação entre crescimento e desenvolvimento sustentável. Proteção aos recursos ambientais não necessariamente implica em diminuição do crescimento econômico. Por outro lado, também é questionável o argumento de que só o crescimento econômico pode garantir proteção ambiental.

Quanto maior for o crescimento econômico de uma determinada sociedade, maior tende a ser sua preocupação com o desenvolvimento de tecnologias limpas. Porém, sendo maior a produção econômica, maior costuma ser também a quantidade de recursos naturais a serem apropriados. Mas isso não é uma regra. Essa idéia é resumida pela autora de forma bastante clara:

"De qualquer forma, o problema do esgotamento dos recursos naturais não é diretamente proporcional ao aumento ou diminuição do crescimento econômico. A velocidade da destruição dos recursos naturais está diretamente comprometida com a forma em que se dá a sua apropriação pela sociedade. A quantidade de transformação de matéria e de energia não depende do crescimento econômico, mas das características da atividade econômica."

Seguindo essa linha de pensamento, Alejandro Altamirano sustenta que:

"Este problema es de compleja y difícil solución, toda vez que podría ser tan perjudicial mantener invariablemente el fenómeno contaminante como erradicarlo totalmente. Además no todo proceso industrial que genera contaminación lo hace en niveles intolerables, pues algunos de estos efectos son subsanados por la propia naturaleza. Consecuentemente se debería reducir este fenómeno a la mínima expressión posible llevándolo a la frontera de tolerancia, en donde la naturaleza pueda neutralizar el deterioro por si misma.

Será entonces necesario que el Estado participe activamente con el fin de fijar una politica ambiental razonable, tendiente a la protección de los recursos naturales pero de forma tal que el cumplimiento de dicho objetivo no trabe irrazonablemente el desarrollo industrial ya que éste, en gran medida, tiene por fin el mejoramiento de la calidad de vida.

\footnotetext{
${ }^{36}$ DERANI, Cristiane. Direito Ambiental Econômico. São Paulo: Max Limonad, 1997. p. 105.
} 
Aparece así un problema de política económica cuya solución deberá enlazarse con un criterio de contaminación llevado a niveles aceptables y cuidando de no hacer inoperable el sistema económico." ${ }^{\text {"37 }}$

\subsubsection{O Desenvolvimento Sustentável e a CF 88}

A Constituição Federal de 1988 incorporou de forma expressa o princípio do desenvolvimento sustentável, tanto no caput do artigo 225, pela preocupação com a manutenção de um meio ambiente ecologicamente equilibrado para as presentes e futuras gerações, quanto no artigo $170, \mathrm{~V}$, tendo firmado a defesa do meio ambiente como princípio conformador da ordem econômica.

Assim, o objetivo previsto no artigo $3^{\circ}$, II da Constituição Federal, de garantir o desenvolvimento nacional, deve ser realizado com a observância dos valores acima mencionados.

\subsubsection{Princípio do Poluidor Pagador}

“O princípio do poluidor pagador visa à internalização dos custos relativos externos de deterioração ambiental, e como conseqüência, a um maior cuidado na busca de uma satisfatória qualidade do meio ambiente. ${ }^{\text {,3 }}$ Por esse princípio, aquele que causar alguma poluição ambiental deverá arcar com os custos e com as medidas da prevenção e mitigação do dano.

O princípio do poluidor pagador está contemplado na Lei 6.938/81, no $\operatorname{artigo~} 4^{\circ}$, VII, como um dos objetivos da Política Nacional do Meio Ambiente: "à imposição, ao poluidor e ao predador, da obrigação de recuperar elou

\footnotetext{
37 ALtamiRANO, Alejandro C. El Derecho Constitucional a un Medio Ambiente Sano, Derechos Humanos y su Vinculación com el Derecho Tributario. P. 19 - 93. In MARINS, James (coord.). Tributação e Meio Ambiente - Livro 2. Curitiba: Juruá, 2004.

${ }^{38}$ MODÉ, Fernando Magalhães. Tributação Ambiental - a função do tributo na proteção do meio ambiente. Curitiba: Juruá, 2003. p. 63.
} 
indenizar os danos causados e, ao usuário, da contribuição pela utilização de recursos ambientais com fins econômicos" (grifamos).

A conseqüência da aplicação deste princípio está prevista na mesma Lei, no artigo 14, $\S 3^{\circ}$ : "Sem obstar a aplicação das penalidades previstas neste artigo, é o poluidor obrigado, independentemente da existência de culpa, a indenizar ou reparar os danos causados ao meio ambiente e a terceiros, afetados por sua atividade".

O artigo $4^{\circ}$, VII da Lei 6.938/81 também explicita o princípio do usuário pagador que, por sua vez,

“estabelece que os recursos naturais devem estar sujeitos à aplicação de instrumentos econômicos para que o seu uso e aproveitamento se processem em benefício da coletividade; portanto, a apropriação desses recursos por um ente privado ou público deve garantir à coletividade o direito a uma compensação financeira. Esses princípios têm por objetivo fazer com que os custos não sejam suportados nem pelo Poder Público nem por terceiros, mas sim pelos utilizadores." 39

O princípio do poluidor pagador também foi incorporado na Declaração do Rio - 92, com o seguinte conteúdo:

"Princípio 16: As autoridades nacionais deverão envidar esforços no sentido de promover a internalização dos custos ambientais e o uso de instrumentos econômicos, levando em consideração a política de que o poluidor deverá, em princípio, arcar com os custos da poluição, considerando o interesse público e sem distorcer-se o comércio e as inversões internacionais".

A origem deste princípio está no problema das chamadas “externalidades negativas". Fernando Modé observa que:

"São chamadas externalidades porque, embora resultantes da produção, são recebidas pela coletividade, ao contrário do lucro, que é

\footnotetext{
${ }^{39}$ MOUSINHO, Patrícia. Glossário. p. 333-367. in TRIGUEIRO, André (coord.). Meio Ambiente no Século 21: 21 especialistas falam da questão ambiental nas suas áreas de conhecimento. $2^{\mathrm{a}}$ ed. Rio de Janeiro: Sextante, 2003.
} 
percebido pelo produtor privado. Daí a expressão 'privatização dos lucros e socialização das perdas', quando identificadas as externalidades negativas. Com a aplicação do princípio do poluidor pagador, procura-se corrigir este custo adicionado à sociedade, impondo-se sua internalização". ${ }^{40}$

\subsubsection{Externalidades da Produção Econômica e a Internalização dos Custos Ambientais}

A produção de um bem ou sua utilização podem acarretar efeitos positivos ou negativos, suportados pelo próprio produtor, ou por toda a coletividade que sequer participou da cadeia produtora ou consumidora do produto. Quando os efeitos da produção ficam retidos no âmbito do próprio produtor, tem-se que tais resultados são efeitos internos; trata-se de efeitos externos quando, ao contrário, o produtor não consegue conter os efeitos de sua produção, ou não se interessa em fazê-lo.

Esses efeitos externos são as chamadas externalidades ${ }^{41}$, que poderão trazer conseqüências positivas (ganhos) ou negativas (perdas) à sociedade. No conceito de Mankiw, "uma externalidade é o impacto das ações de uma pessoa sobre o bem-estar de outras que não participaram da ação" ${ }^{\text {"42 }}$.

Assim, se apresenta o problema de como evitar essas externalidades e, já tendo elas ocorrido, ou sendo inevitáveis, de como estabelecer meios para que os responsáveis arquem com a compensação dos danos.

$\mathrm{O}$ conceito de externalidade é um fundamento da teoria econômica para as políticas ambientais. "Segundo essa visão, a melhor recomendação política é

\footnotetext{
${ }^{40}$ MODÉ, Fernando Magalhães. Tributação Ambiental - a função do tributo na proteção do meio ambiente. Curitiba: Juruá, 2003. p. 63.

41 "Consideram-se negativas as externalidades, 'quando uma atividade impõe custos não indenizados às pessoas. Neste caso, o custo social de um bem (o custo com que todos arcam) excede o custo privado (o custo arcado pelos produtores do bem)'. São positivas as externalidades, 'quando uma atividade cria benefícios para as pessoas, sem que essas precisem pagar por eles. Neste caso, o benefício social do bem (o benefício que todos recebem) supera o seu benefício privado (os benefícios daqueles que pagaram pelo bem)." (NUNES, Cleucio Santos. Direito Tributário e Meio Ambiente. São Paulo: Dialética, 2005. p. 98.)

${ }^{42}$ MANKIW, N. Gregory. Introdução à Economia: princípios de micro e macroeconomia. 2. ed. Tradução de Maria José Cyhlar Monteiro. Rio de Janeiro: Campus, 2001. p. 208.
} 
a aplicação de instrumentos econômicos que incentivem os agentes a considerarem os custos sociais nas suas decisões individuais."43

No que tange às externalidades negativas, o instrumento seria a tributação ambiental. Os tributos incidirão sobre as atividades produtivas poluidoras, considerando-se que o dano ambiental é uma perda social muito grave. Assim, caso um produtor provoque dano a um bem de terceiro, como resultado de sua produção, o custo da reparação desse dano deve ser internalizado pelo produtor, e não suportado pelo terceiro, sob pena de desequilibrar o mercado.

Além disso, sendo a atividade é potencialmente poluidora, deve o empreendedor arcar com os custos da diminuição, eliminação ou neutralização do dano.

A Constituição do Estado do Rio de Janeiro consagrou expressamente a orientação financeira decorrente do princípio do poluidor pagador, ao determinar a adoção de "política tributária que implemente o princípio do poluidor-pagador" 44 .

Silvio Alexandre Fazolli salienta que "determinados quais os níveis permitidos de poluição - pois não existe atividade isenta de prejuízo ecológico -, o princípio do poluidor-pagador terá aplicação na majoração dos tributos referentes às atividades de maior potencial degradador." 45

Já no tocante às externalidades positivas, seriam aplicados os incentivos fiscais. Isso porque a ocorrência de externalidades positivas revela que os custos privados da produção são maiores do que os sociais. Um exemplo seria o de certa tecnologia para produzir um bem e de seu emprego que, por conseqüência, traz a diminuição da poluição atmosférica. Mas o produtor dessa tecnologia possui um custo para produzir o bem que demanda a alocação de

\footnotetext{
${ }^{43}$ GUERRA, Sinclair Mallet-Guy; SUAREZ, Miriam Liliana Hinostroza. Questões Econômicas e Implicações Ambientais: Visão Introdutória. Revista de Direito Ambiental. São Paulo, n. 8. p. 84-106. ${ }^{44}$ Constituição do Estado do Rio de Janeiro, art. 258, § $1^{\circ}$, XVIII.

45 FAZOLLI, Silvio Alexandre. Princípios Ambientais Tributários e Extrafiscalidade. Revista de Direito Ambiental. São Paulo, n. 34. p. 78-82.
} 
muitos recursos. Isso faz com que sua produção seja inferior ao benefício social que aquela poderia alcançar caso fosse estimulada. Nesse sentido, a intervenção estatal é útil ao alcance do equilíbrio do mercado, na medida em que dará estímulo suficiente ao aumento da tecnologia não poluente, usando o incremento de incentivos fiscais.

Esse mesmo raciocínio também é desenvolvido por Alejandro Altamirano:

"El problema esencial aparece cuando en que el precio de los productos elaborados y que han generado contaminación, no se refleja el dano que causan. El productor tiene pocas razones para instalar costosos equipos para prevenir el fenômeno. Si instala tales equipos y sus competidores no lo hacen, quedará em inferioridad de condiciones, tendrá menos ventas y menos ganâncias debido a que solo él internalizó el costo de la polución." 46

\subsubsection{Princípio do Não-Poluidor Recebedor / Protetor Recebedor}

Consoante o princípio do protetor recebedor, aquele agente público ou privado que protege um bem natural em benefício da comunidade deve receber uma compensação financeira como incentivo pelo serviço de proteção ambiental prestado. Pelo princípio do protetor recebedor, receberá incentivos econômicos o agente que, deixando de utilizar os recursos de uma determinada área, contribui para a sua preservação. Pode ser considerado como o oposto do princípio do usuário pagador, abordado acima. ${ }^{47}$

O princípio do protetor recebedor também pode ser utilizado pela faceta do princípio do não-poluidor recebedor, segundo o qual todo agente público que deixar de poluir deve receber um incentivo ou prêmio por essa atitude,

\footnotetext{
${ }^{46}$ AltamiRANO, Alejandro C. El Derecho Constitucional a un Medio Ambiente Sano, Derechos Humanos y su Vinculación com el Derecho Tributario. In MARINS, James (coord.). Tributação e Meio Ambiente - Livro 2. Curitiba: Juruá, 2004. Pg 11-93.

${ }^{47}$ RIBEIRO, Maurício Andrés. O Princípio Protetor-Recebedor para preservar um bem natural. Disponível em: <www.eco21.com.br> Acesso em 10.mai.2005.
} 
diferenciando-se daqueles agentes que ainda continuem a poluir o ambiente. Neste caso, trata-se do inverso do princípio do poluidor pagador. ${ }^{48}$

A aplicação do princípio do protetor recebedor e do não-poluidor recebedor pode se dar de várias formas. Uma delas, que é o objeto principal do presente trabalho, é o ICMS Ecológico. De uma forma bastante resumida, significa que aqueles municípios que protegerem mais o meio ambiente, seja investindo ou, simplesmente, deixando de utilizar recursos naturais, receberão maior parcela do repasse do ICMS (imposto sobre operações relativas à circulação de mercadorias e sobre prestações de serviços de transporte interestadual e intermunicipal e de comunicação).

\footnotetext{
${ }^{48}$ RIBEIRO, Maurício Andrés. O Princípio Protetor-Recebedor para preservar um bem natural.
} Disponível em: <www.eco21.com.br> Acesso em 10.mai.2005. 


\section{Tributação Ambiental}

\subsection{Introdução}

Ao enfrentar o tema do controle das externalidades negativas, buscando harmonizar os interesses econômicos e a preservação do meio ambiente para as gerações futuras, merece destaque a figura da tributação ambiental, mostrandose como um instrumento econômico promissor na luta pelo desenvolvimento sustentável. Assim, “o tributo ecologicamente orientado deverá 'internalizar’ os custos ambientais, isto é, trazer para dentro do custo do produto o montante exigido pela reparação ambiental do mal que causa"49.

Alfredo Augusto Becker e José Marcos Domingues de Oliveira apontam esse caráter inovador do Direito Tributário:

“ 'Não a um Direito Tributário nos moldes atuais, ainda rudimentar, porque cheio de inibições que paralisam e esterilizam muitas de suas genuínas potencialidades'... ${ }^{50}$

mas, sim, a um Direito Tributário dinâmico e inovador, comprometido com os anseios da Humanidade." 51

José Marcos Domingues de Oliveira destaca, ainda, que

“ 'os tributos ambientais (écotaxes), desde que adequadamente concebidos e postos em prática, podem ter uma real eficácia em matéria de proteção do meio ambiente'. (...) 'Desde o início dos anos 90, observa-se uma certa forma de integração das considerações do meio ambiente nos sistemas fiscais de vários países da $\mathrm{OCDE}^{52, ", 53}$

\footnotetext{
49 FERRAZ, Roberto. Tributação e Meio Ambiente: o green tax no Brasil (a contribuição de intervenção da Emenda 33/2001). Revista de Direito Ambiental. São Paulo, n 31. p. 167-172.

${ }^{50}$ BECKER, Alfredo Augusto. Teoria Geral do Direito Tributário. 2a ed. São Paulo: Saraiva, 1972. p. 533. apud OLIVEIRA, José Marcos Domingues de. Direito Tributário e Meio Ambiente: Proporcionalidade, Tipicidade Aberta e Afetação da Receita. 2a ed. Rio de Janeiro: Renovar, 1999, p. 13.

${ }^{51}$ OLIVEIRA, José Marcos Domingues de. Direito Tributário e Meio Ambiente: Proporcionalidade, Tipicidade Aberta e Afetação da Receita. $2^{\mathrm{a}}$ ed. Rio de Janeiro: Renovar, 1999. p. 13.

52 Organização para a Cooperação e o Desenvolvimento Econômico.
} 


\subsection{Finalidade Extrafiscal dos Tributos Ambientais e as Formas de sua Implementação}

A tributação, dependendo dos fins colimados pelo legislador, pode ser classificada em fiscal, parafiscal e extrafiscal.

A fiscalidade corresponde à natureza puramente arrecadatória do tributo, sem finalidade específica. ${ }^{54}$ Visa, exclusivamente, à arrecadação de recursos financeiros para prover ao custeio dos serviços públicos.

Os tributos com finalidade parafiscal destinam-se ao custeio de atividades paralelas à da administração pública direta, como, por exemplo, a seguridade social (artigo 195 da Constituição Federal).

A Constituição Federal, em seu artigo 151, I, expõe que a instituição do tributo pode ter outros objetivos que não sejam o da arrecadação financeira ao erário, admitindo a concessão de incentivos fiscais que visem à promoção do desenvolvimento socioeconômico entre as diferentes regiões do país, buscando atingir a justiça social.

Dessa forma, a extrafiscalidade visa à consecução de objetivos relacionados ao bem comum. A tributação extrafiscal atende "a fins outros que não a arrecadação, mas, geralmente, à correção de situações sociais indesejadas e à condução da economia, através do estímulo e do desestímulo de certas atividades.", 55

Hely Lopes Meirelles salienta que:

\footnotetext{
${ }^{53}$ Écotaxes et Reforme Fiscale Verte, Paris, reimpr. 1997, pp.12; 20. in OLIVEIRA, José Marcos Domingues de. Direito Tributário e Meio Ambiente: Proporcionalidade, Tipicidade Aberta e Afetação da Receita. $2^{\text {a }}$ ed. Rio de Janeiro: Renovar, 1999. p. 13-14.

${ }^{54}$ FAZOLLI, Silvio Alexandre. Princípios Ambientais Tributários e Extrafiscalidade. Revista de Direito Ambiental. São Paulo, n. 34. p. 78-83.

55 OLIVEIRA, José Marcos Domingues de. Direito Tributário e Meio Ambiente: Proporcionalidade, Tipicidade Aberta e Afetação da Receita. $2^{a}$ ed. Rio de Janeiro: Renovar, 1999. p. 31.
} 
"A extrafiscalidade é a utilização do tributo como meio de fomento ou desestímulo a atividades reputadas convenientes ou inconvenientes à comunidade. É ato de polícia físcal, isto é, de ação do governo para o atingimento de fins sociais através da maior ou menor imposição tributária." ${ }^{56}$

No caso da tributação ambiental, verificam-se duas finalidades: a fiscal e a extrafiscal. A primeira finalidade visa à obtenção de receitas que serão aplicadas em ações que promovam a defesa do meio ambiente. A segunda finalidade tem por objetivo induzir comportamentos que, na visão do Estado, sejam ambientalmente desejáveis ou de menor poder ofensivo ao meio ambiente.

A tributação extrafiscal pode ser implementada por meio da instituição de novos tributos, graduação dos tributos já existentes, concessão de isenções e outros benefícios, como a possibilidade de dedução de despesas efetuadas pelos contribuintes com recursos empregados na preservação do meio ambiente. $^{57}$

O melhor meio é o da concessão dos chamados privilégios não-odiosos, que pode se dar sob a forma negativa (isenções ${ }^{58}$ e reduções de alíquotas) ou

\footnotetext{
${ }^{56}$ MEIRELLES, Hely Lopes. Direito Administrativo Brasileiro. $24^{\mathrm{a}}$ ed. São Paulo: Malheiros, 1999. p. 45.

${ }^{57}$ ARAÚJO, Cláudia Campos de et al.. Meio Ambiente e Sistema Tributário: Novas Perspectivas. São Paulo: Senac, 2003. p. 115.

58 "A isenção fiscal é a principal espécie de privilégio fiscal de natureza negativa, admissível no sistema jurídico brasileiro, desde que não seja odiosa. Ao tratar dos motivos e causas para a concessão de isenções, Aliomar Baleeiro entendia que era inconcebivel a isenção geral e universal, a de todos os tributos, por isso mesmo que ela, no mundo contemporâneo, não é privilégio de classe ou de pessoas, mas uma política de aplicação da regra da capacidade contributiva ou de incentivos a determinadas atividades, que o Estado visa a incrementar pela conveniência pública.

A isenção tributária tem por finalidade a aplicação de uma política de incentivo a determinadas atividades, bem como a busca da justiça fiscal em relação a certos indivíduos, dentro de um contexto de observância de princípios relacionados à capacidade contributiva, e princípios econômicos, considerando certos critérios que não sejam discriminatórios ou distintivos." (GAMA, Guilherme Calmon Nogueira da. Os Privilégios Fiscais: Isenções e Incentivos Fiscais. Revista de Direito Tributário, $\mathrm{n}^{\mathrm{o}}$ 76. p. 215-225.)
} 
sob a forma positiva (incentivos e subsídios), sendo fundada no princípio da justiça ou no princípio do desenvolvimento econômico. ${ }^{59}$

Seria inviável a criação de novos tributos ou a majoração de alíquotas dos já existentes, uma vez que o Brasil possui carga tributária extremamente alta, sendo, inclusive, uma das maiores do mundo. Nas palavras do Professor Marcelo Figueiredo:

"É preciso perceber que a engenharia tributária poderá criar mecanismos de estímulo à preservação, de tal maneira que não se onere a carga tributária, mas que se passe a idéia ao empresariado nacional, através de normas competentes, que essa atividade - preservar o meio ambiente pode ser, inclusive, um 'bom negócio'. E como é que pode ser um bom negócio? Pode ser, desde que haja prêmios, incentivos, isenção tributária por décadas etc. $" 60$

Cleucio Santos Nunes conclui que "tributando atividades poluidoras ou deixando de tributar as atividades 'limpas', o resultado é a continuidade do desenvolvimento do sistema, porém em bases razoáveis de exploração de recursos naturais e aproveitamento adequado dos produtos transformados". ${ }^{61}$

Silvio Alexandre Fazolli evidencia que

\begin{abstract}
"Na seara do direito tributário, o oferecimento de incentivos fiscais (descontos, alíquotas diferenciadas, isenção, etc.) é um dos fatores que mais têm chamado a atenção do cidadão/contribuinte, tornando a preservação ambiental uma atitude convidativa. No Estado do Paraná, v.g., todo aquele que mantiver em sua propriedade área de Reserva Particular do Patrimônio Natural - RPPN terá isenção de ITR no que corresponde à área preservada e preferência na obtenção de financiamentos agrícolas, entre outros benefícios." 62
\end{abstract}

\footnotetext{
${ }^{59}$ GAMA, Guilherme Calmon Nogueira da. Os Privilégios Fiscais: Isenções e Incentivos Fiscais. Revista de Direito Tributário, n. 76. p. 215-225.

${ }^{60}$ FIGUEIREDO, Marcelo. Tributação, Ecologia e Meio Ambiente - Mesa de Debates "C". Revista de Direito Tributário, n 78. p. 69-89.

${ }^{61}$ NUNES, Cleucio Santos. Direito Tributário e Meio Ambiente. São Paulo: Dialética, 2005. p. 107.

${ }^{62}$ FAZOLLI, Silvio Alexandre. Princípios Ambientais Tributários e Extrafiscalidade. Revista de Direito Ambiental. São Paulo, n. 34. p. 78-83.
} 
A extrafiscalidade permite ao contribuinte alternativa de escolha entre um gravame mais ameno e nenhum gravame tributário, conforme sua atuação se desenvolva. ${ }^{63}$ Ou seja,

"no caso dos incentivos fiscais empregados como instrumentos econômicos de promoção da defesa do meio ambiente, entende-se que a rejeição por uns do estímulo fiscal (escolha de continuar poluindo) implica em pagar mais imposto, em relação à opção de outros de evoluir tecnologicamente e, não poluindo, pagar menos imposto ou não pagar imposto algum." ${ }^{14}$

Destarte, mediante a implementação da tributação ambiental, os agentes poluidores permanecem livres para se adaptarem da maneira que melhor thes convier ao padrão definido pelo Estado. Poderão agir, por exemplo, diminuindo os impactos ambientais causados por sua atividade econômica através da redução da produção de resíduos, do incremento tecnológico às suas instalações, do aumento da eficiência do processo produtivo ou do uso de substâncias menos poluidoras no processo produtivo, sejam elas empregadas como matéria-prima, material de embalagem ou mesmo consumidas ao longo do processo.

Para Fernando Magalhães Modé,

"A tributação ambiental coloca-se ainda, em face do agente econômico, como um incentivo permanente para a redução da poluição aos níveis ótimos definidos pelo Estado. $\mathrm{Na}$ busca do melhor resultado econômico o agente poluidor sente-se impulsionado a tentar novas técnicas e a inovar os métodos de produção que lhe permitam uma redução da carga fiscal suportada". ${ }^{5}$

O objetivo principal da tributação ambiental é a proteção do meio ambiente através da aplicação do seu princípio mais importante, o da

\footnotetext{
${ }^{63}$ OLIVEIRA, José Marcos Domingues de. Direito Tributário e Meio Ambiente: Proporcionalidade, Tipicidade Aberta e Afetação da Receita. $2^{\mathrm{a}}$ ed. Rio de Janeiro: Renovar, 1999, p. 38.

${ }^{64}$ OLIVEIRA, José Marcos Domingues de. Direito Tributário e Meio Ambiente: Proporcionalidade, Tipicidade Aberta e Afetação da Receita. $2^{\mathrm{a}}$ ed. Rio de Janeiro: Renovar, 1999, p. 40.

${ }^{65}$ MODÉ, Fernando Magalhães. Tributação Ambiental - a função do tributo na proteção do meio ambiente. Curitiba: Juruá, 2003. p. 97.
} 
prevenção. Atuando na indução das ações dos agentes econômicos, poluidores em potencial, objetiva que tais agentes econômicos alterem seu comportamento para um modo mais compatível com a manutenção do equilíbrio ambiental, agindo, assim, antes da ocorrência do dano, afastando sua ocorrência ou minimizando seus efeitos.

A tributação ambiental possibilita a socialização da responsabilidade sobre a preservação do meio ambiente com uma maior carga sobre os agentes econômicos que efetivamente mais contribuem para o desequilíbrio ambiental. A aplicação do princípio do poluidor pagador, por via tributária, permite a repartição dos custos internalizados em toda a cadeia de produção, resultando numa distribuição mais justa dos encargos decorrentes, atenuando ou até eliminando o impacto das externalidades negativas produzidas.

$\mathrm{Na}$ opinião de José Marcos Domingues de Oliveira, o princípio do poluidor pagador tem dois sentidos. No sentido impositivo, que se adequa à tributação fiscal, significa que deve ser imputado ao poluidor o rateio do custo das ações estatais necessárias à preservação e recuperação ambientais. Num outro sentido, o seletivo, o princípio determina prioritariamente ao Poder Público que gradue a tributação de forma a incentivar atividades, processos produtivos ou consumos "ecologicamente corretos", e desestimular o emprego de tecnologias defasadas, a produção e o consumo de bens "ecologicamente incorretos". É, como se percebe, o campo da tributação extrafiscal. ${ }^{66}$

É importante ressaltar que a aplicação do princípio do poluidor pagador não confere ao agente econômico um direito a poluir, ou seja, os instrumentos econômicos não devem ser utilizados para regular atividades que devam ser consideradas proibidas, pelo seu próprio potencial danoso. A indução de comportamentos deve ser aplicada exclusivamente àquelas atividades

\footnotetext{
${ }^{66}$ OLIVEIRA, José Marcos Domingues de. Direito Tributário e Meio Ambiente: Proporcionalidade, Tipicidade Aberta e Afetação da Receita. $2^{\text {a }}$ ed. Rio de Janeiro: Renovar, 1999, p. 42-43.
} 
reconhecidas pela sociedade como necessárias, muito embora guardem um certo impacto ao meio ambiente.

Outra questão que deve ser mencionada quando se trata de tributação ambiental é a de que, conforme estudos da Organização para a Cooperação e o Desenvolvimento Econômico (OCDE), “a implementação da tributação ambiental deve ser feita de tal forma que a carga fiscal global sobre determinada economia não se altere", ${ }^{67}$

A Lei de Responsabilidade Fiscal (Lei Complementar 101/2000) segue este mesmo raciocínio, quando prevê no seu artigo 14 que

"Art. 14. A concessão ou ampliação de incentivo ou benefício de natureza tributária da qual decorra renúncia de receita deverá estar acompanhada de estimativa do impacto orçamentário-financeiro no exercício em que deva iniciar sua vigência e nos dois seguintes, atender ao disposto na lei de diretrizes orçamentárias e a pelo menos uma das seguintes condições:

I - demonstração pelo proponente de que a renúncia foi considerada na estimativa de receita da lei orçamentária, na forma do art. 12, e de que não afetará as metas de resultados fiscais previstas no anexo próprio da lei de diretrizes orçamentárias;

II - estar acompanhada de medidas de compensação, no período mencionado no caput, por meio do aumento de receita, proveniente da elevação de alíquotas, ampliação da base de cálculo, majoração ou criação de tributo ou contribuição.

$\S 10$ A renúncia compreende anistia, remissão, subsídio, crédito presumido, concessão de isenção em caráter não geral, alteração de alíquota ou modificação de base de cálculo que implique redução discriminada de tributos ou contribuições, e outros benefícios que correspondam a tratamento diferenciado.

$\S 2$ o Se o ato de concessão ou ampliação do incentivo ou benefício de que trata o caput deste artigo decorrer da condição contida no inciso II, o benefício só entrará em vigor quando implementadas as medidas referidas no mencionado inciso.

$\S 30 \mathrm{O}$ disposto neste artigo não se aplica:

I - às alterações das alíquotas dos impostos previstos nos incisos I, II, IV e V do art. 153 da Constituição, na forma do seu $§ 10$;

II - ao cancelamento de débito cujo montante seja inferior ao dos respectivos custos de cobrança."

\footnotetext{
${ }^{67}$ MODÉ, Fernando Magalhães. Tributação Ambiental - a função do tributo na proteção do meio ambiente. Curitiba: Juruá, 2003. p. 100.
} 


\section{ICMS Ecológico}

3.1. ICMS

$\mathrm{O} \mathrm{ICMS}^{68}$ é um tributo de competência estadual, que representa a maior parte da receita tributária dos Estados e constitui importante fonte de renda para os Municípios, incidindo sobre a circulação de mercadorias e alguns serviços.

No Estado do Rio de Janeiro, por exemplo, a arrecadação acumulada no ano de 2004 foi de $\mathrm{R} \$ 12.867 .899 .039$ (doze bilhões, oitocentos e sessenta e sete milhões, oitocentos e noventa e nove mil e 39 reais ${ }^{69}$. No atual ano de 2005, a arrecadação referente aos meses de janeiro a março já atingiu R\$3.393.307.192 (três bilhões, trezentos e noventa e três milhões, trezentos e sete mil e cento e noventa e dois reais $)^{70}$.

\subsection{ICMS Ecológico}

\subsubsection{Conceito e Histórico}

O ICMS Ecológico tem representado um avanço na busca de um modelo de gestão ambiental compartilhada entre os Estados e Municípios no Brasil, com reflexos objetivos em vários temas, em especial a conservação da biodiversidade, através da busca da proteção das unidades de conservação e outros espaços especialmente protegidos.

\footnotetext{
${ }^{68}$ Imposto sobre operações relativas à circulação de mercadorias e sobre prestações de serviços de transporte interestadual e intermunicipal e de comunicação.

${ }^{69}$ Disponível em

$<$ http://www.receita.rj.gov.br/info/arrecadacao/dados_arrec/icms/comp_anual/2004_comp_anual.pdf $>$ Acesso em 10.mai.2005.

${ }^{70}$ Disponível em

$<$ http://www.receita.rj.gov.br/info/arrecadacao/dados_arrec/icms/comp_anual/2005_comp_anual.pdf $>$ Aceso em 10.mai.2005.
} 
Éderson Pires observa que:

"Na verdade, não se trata de uma nova modalidade de tributo ou uma espécie de ICMS, parecendo mesmo que a denominação é imprópria a identificar o seu verdadeiro significado, de vez que não há qualquer vinculação do fato gerador do ICMS a atividades de cunho ambiental. Da mesma forma, como não poderia deixar de ser, não há vinculação específica da receita do tributo para financiar atividades ambientais.

Não obstante, a expressão já popularizada ICMS Ecológico está a indicar uma maior destinação de parcela do ICMS aos municípios em razão de sua adequação a níveis legalmente estabelecidos de preservação ambiental e de melhoria da qualidade de vida, observados os limites constitucionais de distribuição de receitas tributárias e os critérios técnicos definidos em lei." ${ }^{, 71}$

Assim, como instrumento de gestão ambiental, o ICMS Ecológico instala o critério ambiental na redistribuição do imposto, permitindo ao Estado influir no processo de desenvolvimento sustentável dos municípios.

Diante da enorme quantidade de recursos arrecadados com o ICMS, direcioná-los em benefício do meio ambiente é, sem dúvida, poderoso instrumento, que poderá trazer resultados positivos se aplicado e físcalizado corretamente, evitando distorções e desvios de sua finalidade.

Como o principal critério de redistribuição é o valor adicionado fiscal (VAF), que reflete o nível de atividade econômica do município e conseqüente participação na arrecadação, o ICMS acaba por estimular o estabelecimento de novas atividades comerciais e industriais. Esse critério prejudica os municípios que impõem restrições ao uso da terra, devido à adoção de áreas protegidas. ${ }^{72}$ Esses municípios, entretanto, geram serviços ambientais que não possuem mercado, mas que resultam em qualidade de vida. Conseqüentemente, os

\footnotetext{
71 PIRES, Éderson. Icms ecológico. Aspectos pontuais. Legislação comparada. Jus Navigandi, Teresina, a. 6, n. 52, nov. 2001. Disponível em: $<$ http://www1.jus.com.br/doutrina/texto.asp?id=2328>. Acesso em 31.mar.2005.

${ }^{72}$ Disponível em

$<$ http://www.wwf.org.br/projetos/projeto.asp?lista=bioma\&item=19\&item=73\&imagem=../bioma/int nacional> Acesso em 05.mai.2005.
} 
municípios que têm unidades de conservação merecem receber um pouco mais por isso.

Utilizando-se da possibilidade prevista no inciso II do parágrafo único do artigo 158 da Constituição Federal e na disposição contida no artigo 132 de sua Constituição Estadual, o estado do Paraná, em projeto pioneiro no Brasil, instituiu, em 1991, pela Lei 59/91, o denominado ICMS Ecológico.

No Paraná, a discussão a respeito desse tema se iniciou devido ao interesse de muitos municípios que tinham seus territórios limitados pela proteção ambiental. Eles se organizaram e buscaram apoio técnico e político, visando à identificação de alternativas de financiamento público para o desenvolvimento de atividades econômicas que sofressem restrições ambientais. Isso resultou na criação do ICMS Ecológico. ${ }^{73}$

Além disso, o ICMS Ecológico reflete o espírito da Convenção sobre Diversidade Biológica assinada na Rio 92. É uma tentativa de agregar às atividades de proteção ambiental um valor econômico, como forma de estimulá-las.

Portanto, "nascido sob a égide da 'compensação,74, o ICMS Ecológico evolui, transformando-se ao longo do tempo também em instrumento de incentivo, direto e indireto à conservação ambiental, hoje o que mais o caracteriza." 75

No entanto, conforme destaca Wilson Loureiro,

\footnotetext{
${ }^{73}$ ARAÚJO, Cláudia Campos de et al.. Meio Ambiente e Sistema Tributario: Novas Perspectivas. São Paulo: Senac, 2003. p. 40.

${ }^{74}$ Tratava-se de uma compensação, pois os municípios que estavam aptos a receber o ICMS Ecológico eram aqueles que, por restrições ambientais previstas em lei (unidades de conservação e mananciais de abastecimento público para municípios vizinhos) não podiam desenvolver atividades econômicas que gerassem ICMS. Não gerando ICMS, também não seriam beneficiados quando da distribuição dos recursos arrecadados, já que, em regra, o critério da distribuição do ICMS para os municípios é o do VAF (previsto no artigo 158, parágrafo único, I, CF). Assim, os municípios eram compensados porque, apesar de não gerarem receita de ICMS, geravam benefícios ambientais, que resultavam em qualidade de vida para toda a coletividade.

75 LOUREIRO, Wilson. O ICMS biológico na biodiversidade. Disponível em $<$ http://www.universoverde.com.br/indexa/inicio.htm>. Acesso em 29 mar. 2005.
} 
"Existe a necessidade de que o ICMS Ecológico seja explorado o mais rapidamente possível, tornando efetiva sua intervenção, posto que a concepção deste instrumento traz dentro de si uma contradição, que pode diminuir sua atratividade ao longo do tempo. Isto significa que mantido o mesmo percentual de repasse aos municípios, bem como os mesmos níveis de arrecadação, à medida que novos municípios passam a se beneficiar, que áreas que já beneficiam municípios tenham sua superfície aumentada ou, acima de tudo, que haja melhoria da qualidade das áreas protegidas, existe a tendência da diminuição dos recursos a serem repassados a cada município." ${ }^{, 76}$

Assim, quanto maior for o número de municípios beneficiados, menor a parcela de cada um a ser recebida. Até o presente, entretanto, os recursos do ICMS Ecológico representam importante parcela na composição da receita de muitos municípios.

\subsubsection{Fundamentação Constitucional}

O ICMS encontra-se disciplinado no artigo 155, II, da Constituição Federal, que dispõe:

"Art. 155. Compete aos Estados e ao Distrito Federal instituir impostos sobre:

(...)

II - operações relativas à circulação de mercadorias e sobre prestações de serviços de transporte interestadual e intermunicipal e de comunicação, ainda que as operações e as prestações se iniciem no exterior;"

Quanto ao produto total da arrecadação do ICMS, os Estados dividem com os Municípios situados em seu território essa receita tributária, em razão do disposto no artigo 158, IV, da Constituição Federal, que fixa:

\footnotetext{
${ }^{76}$ LOUREIRO, Wilson. Contribuição do ICMS Ecológico à Conservação da Biodiversidade no Estado do Paraná. Tese de Doutorado apresentada ao Curso de Pós-Graduação em Engenharia Florestal da Universidade Federal do Paraná. Curitiba, 2002. Disponível em $<$ http://pinho.floresta.ufpr.br/pos-graduacao/seminarios/wilson/contribuicao_do_icms.pdf $>$. Acesso em 5.mai.2005.
} 
“Art. 158. Pertencem aos Municípios:

(...)

IV - vinte e cinco por cento do produto da arrecadação do imposto do Estado sobre operações relativas à circulação de mercadorias e sobre prestações de serviços de transporte interestadual e intermunicipal e de comunicação."

A forma pela qual será realizado esse repasse, do Estado para os Municípios, está inserida no parágrafo único do artigo 158, I e II, da Constituição Federal, que assim determina:

\footnotetext{
“Art. 158. (...)

Parágrafo único. As parcelas de receita pertencentes aos Municípios, mencionadas no inciso IV, serão creditadas conforme os seguintes critérios:

I - três quartos, no mínimo, na proporção do valor adicionado nas operações relativas à circulação de mercadorias e nas prestações de serviços, realizadas em seus territórios;

II - até um quarto, de acordo com o que dispuser lei estadual ou, no caso dos Territórios, lei federal."
}

Assim, alguns Estados estão ampliando as características extrafiscais do ICMS, implantando por força de lei estadual o ICMS Ecológico, que consiste, conforme demonstrado, em parcela resultante da divisão da receita do mencionado imposto, destinando-se aos Municípios um valor redistribuído proporcional ao seu compromisso ambiental.

\subsubsection{Finalidade}

Cada estado da federação estabelece a finalidade imediata do ICMS Ecológico, de acordo com suas prioridades em nível ambiental e até mesmo social, estimulando: ações de saneamento básico; manutenção de sistemas de 
disposição final de resíduos sólidos e redes de tratamento de esgoto; manutenção de mananciais de abastecimento público de água; criação e manutenção de unidades de conservação; investimento em educação e saúde; atividades agropecuárias; incremento de ações fiscais visando ao aumento das arrecadações municipais. No que diz respeito à finalidade mediata, todas as ações estão voltadas à melhoria da qualidade de vida e à garantia do desenvolvimento sustentável. ${ }^{77}$

\title{
3.2.4. Legislação Estadual: critérios adotados
}

Na criação, pelos Estados, do ICMS Ecológico, podem ser estabelecidos critérios quantitativos, qualitativos, ou os dois, concomitantemente.

\begin{abstract}
“A implementação desse incentivo deve considerar as especificidades locais e regionais, além de incorporar outros critérios que potencializam a conservação do ambiente. Questões como as da saúde, da educação e da produtividade por área cultivada possuem implicações diretas sobre as estratégias de conservação ambiental, e o conjunto de critérios de distribuição do ICMS pode ser um fator determinante para a manutenção de um meio ambiente saudável, gerando melhoria direta na qualidade de vida da população, desde que os gestores estaduais e municipais compreendam que se trata de criar condições não apenas para ampliar a receita municipal, mas para modificar padrões prevalecentes de uso dos recursos locais a partir das especificidades e das necessidades da população local de forma democrática e perene. ${ }^{, 78}$
\end{abstract}

\subsubsection{Paraná}

Como já foi dito anteriormente, o Paraná foi pioneiro na instituição do ICMS Ecológico, em 1991. A Constituição do Estado do Paraná, em seu artigo 132, parágrafo único, determina tratamento especial, quanto ao crédito da

\footnotetext{
77 PIRES, Éderson. Icms ecológico. Aspectos pontuais. Legislação comparada. Jus Navigandi, Teresina, a. 6, n. 52, nov. 2001. Disponível em: $<$ http://www1.jus.com.br/doutrina/texto.asp?id=2328 $>$. Acesso em 31.mar.2005.

${ }^{78}$ Disponível em $<$ http://www.anppas.org.br/encontro/segundo/Papers/GT/GT15/ciccarini_nunes.pdf $>$. Acesso em 31.mar.2005.
} 
receita referida no artigo 158, parágrafo único, II, da Constituição Federal, na distribuição da quota-parte do ICMS aos Municípios que tenham parte de seu território integrando unidades de conservação ambiental, ou que sejam diretamente influenciados por elas, ou àqueles com mananciais de abastecimento público.

Esse princípio fez parte da Lei 9.491, de 21 de dezembro de 1990 que, no seu artigo $2^{\circ}$, determinou: regulamentando o art. 132 e seu parágrafo único, da Constituição do Estado do Paraná, aplicar-se-á aos municípios beneficiados por aquela norma, cinco por cento $(5 \%){ }^{79}$

O artigo 132 da Constituição Estadual do Paraná foi regulamentado pela Lei Complementar 59/91, que ficou conhecida como a Lei do ICMS Ecológico. Esta lei contempla os municípios que abriguem em seu território unidades de conservação ambiental, ou que sejam diretamente influenciados por elas, ou aqueles com mananciais de abastecimento público.

Os municípios contemplados na LC 59/91 pelo critério de mananciais são aqueles que abrigam em seu território parte ou o todo de bacias hidrográficas de mananciais de abastecimento público para municípios vizinhos.

$\mathrm{O}$ artigo $2^{\circ}$ da lei orienta que:

\begin{abstract}
“Art. $2^{\circ}$. As unidades de conservação ambiental, a que alude o artigo primeiro são áreas de preservação ambiental, estações ecológicas, parques, reservas florestais, florestas, hortos florestais, área de relevante interesse de leis ou decretos federais, estaduais ou municipais, de propriedade pública ou privada."
\end{abstract}

Cabe observar que, por força da Lei Federal 9.985/2000, que institui o Sistema Nacional de Unidades de Conservação da Natureza, as unidades de conservação dividem-se em dois grupos e abrangem: Unidades de Proteção Integral (Estação Ecológica, Reserva Biológica, Parque Nacional, Monumento

\footnotetext{
79 LOUREIRO, Wilson. O ICMS biológico na biodiversidade. Disponível em $<\mathrm{http} / / /$ www.universoverde.com.br/indexa/inicio.htm $>$. Acesso em 30 mar. 2005.
} 
Natural, e Refúgio de Vida Silvestre) e Unidades de Uso Sustentável (Área de Proteção Ambiental, Área de Relevante Interesse Ecológico, Floresta Nacional, Reserva Extrativista, Reserva de Fauna, Reserva de Desenvolvimento Sustentável, e Reserva Particular do Patrimônio Natural). Assim, as classificações previstas em leis anteriores estão superadas.

Pelo artigo $2^{\circ}$ acima transcrito, podemos verificar que a Lei do Paraná leva em consideração unidades de conservação federais, estaduais e municipais.

No que tange à repartição de 5\% (cinco por cento) do ICMS a que alude o artigo $2^{\circ}$ da Lei Estadual 9.491/90, o artigo $4^{\circ}$ da LC 59/91 estabelece que será feita da seguinte maneira: 50\% (cinqüenta por cento) para municípios com mananciais de abastecimento e os outros 50\% (cinqüenta por cento) para municípios com unidades de conservação ambiental.

O parágrafo único do mesmo artigo determina que, no caso de municípios com sobreposição de áreas com mananciais de abastecimento e unidades de conservação ambiental, será considerado o critério de maior compensação financeira.

A LC 59/91 foi regulamentada pelo Decreto Estadual 2.791, de 27 de dezembro de 1996, e Portarias do Instituto Ambiental do Paraná - IAP, que definiram os critérios técnicos de alocação dos recursos.

O Decreto 2.791/96 estabelece critérios qualitativos e quantitativos e, também, determina que as Unidades de Conservação poderão ter tratamento diferenciado em relação a seu peso ponderado, a ser definido em Portaria do IAP, de acordo com as categorias de manejo e com a seguinte ordem de prioridade: a) Unidades de Conservação de âmbito municipal; b) Unidades de Conservação de âmbito estadual; c) Unidades de Conservação de âmbito federal. 
No que diz respeito às Unidades de Conservação, o processo funciona da seguinte forma: ${ }^{80}$

$1^{\circ}$ ) é preciso, evidentemente, existir a Unidade de Conservação. Para isto, o IAP executa alguns procedimentos administrativos e técnicos. Esses procedimentos visam a, basicamente, verificar se as áreas objeto de análise se ajustam ao conceito de Unidade de Conservação, podendo, conseqüentemente, ser registradas no Cadastro Estadual de Unidades de Conservação - CEUC;

$2^{\circ}$ ) estando a área caracterizada como Unidade de Conservação, esta é registrada automaticamente no CEUC, passando o município a ser beneficiado já no ano seguinte;

$\left.3^{\circ}\right)$ a partir daí, é realizada uma avaliação da qualidade da Unidade de Conservação, que resultará na determinação de um score, ou seja, a Unidade de Conservação passa a ter uma "nota". Este score, desde que positivo, representa um incremento financeiro ao município. Na prática, isto quer dizer que, além de o município ganhar pela existência da Unidade de Conservação (por já ter a área registrada no Cadastro), pode ganhar mais em função do seu nível de qualidade. Este ganho adicional é bastante variável, dependendo do tipo de Unidade de Conservação, de seu âmbito de gestão e domínio, se público ou privado. A recíproca também é verdadeira, se diminuir o score, o que na prática significa a diminuição da qualidade da Unidade de Conservação, diminui automaticamente o dinheiro a ser repassado. E mais, se acontecer de a qualidade cair de tal forma, que a área se descaracterize como Unidade de Conservação (score negativo, por exemplo), não justificando mais ser considerada uma Unidade de Conservação, será excluída do Cadastro e o município perde tudo. Perde os recursos possíveis pelo critério da qualidade e

${ }^{80}$ Disponível em <http://www.pr.gov.br/meioambiente/iap/bio_icms.shtml>. Acesso em 30.mar.2005. 
pelo critério da sua existência, devendo executar uma série de ações para poder solicitar novamente oportunidade de beneficiar-se pela área. Esta orientação funciona para todos os tipos de Unidades de Conservação.

Pelo exposto, observa-se que a Lei do Paraná adota critérios quantitativos e qualitativos para determinar o repasse de receita do ICMS aos municípios.

\subsubsection{São Paulo}

São Paulo foi o segundo estado a adotar o ICMS Ecológico, com a aprovação da Lei 8.510/93. Tal lei estabeleceu o seguinte:

\footnotetext{
"Artigo 1. - Passa a vigorar com a seguinte redação o artigo $1 .^{\circ}$ da Lei $\mathrm{n}^{\circ}$ 3201, de 23 de dezembro de 1981:

'Artigo 1. ${ }^{\circ}$ - Os índices de participação dos municípios no produto de arrecadação do Imposto sobre Operações Relativas à Circulação de Mercadorias e sobre Prestações de Serviços de Transporte Interestadual e Intermunicipal e de Comunicação serão apurados, anualmente, na forma e prazo estabelecidos pelas Secretaria da Fazenda para aplicação no exercício seguinte, com observância dos seguintes critérios:

(...)

V - 0,5\% (zero vírgula cinco por cento), com base no percentual entre a área total, no Estado, dos reservatórios de água destinados à geração de energia elétrica e a área desses reservatórios no município, existentes no exercício anterior, levantadas pela Secretaria de Energia;

VI - $0,5 \%$ (zero vírgula cinco por cento), em função de espaços territoriais especialmente protegidos existentes em cada município e no Estado, observados os critérios estabelecidos no Anexo desta lei;'”
}

Assim, a lei estabeleceu que uma percentagem de 0,5\% dos recursos financeiros deve ser destinada aos municípios que possuem reservatórios de água destinados a geração de energia elétrica e outros $0,5 \%$ aos municípios que possuem Unidades de Conservação. 
Ainda, a Lei 8.510/93 determinou critério quantitativo para o repasse de receita do ICMS, atribuindo pesos diferenciados para os diversos tipos de Unidades de Conservação:

“§ $2 .^{\circ}$ - Para os efeitos do inciso VI a área total considerada como espaço territorial especialmente protegido em cada município será a soma das áreas correspondentes às diferentes unidades de conservação presentes no município, ponderadas pelos seguintes pesos:

I - Estações Ecológicas - peso 1,0 (um);

II - Reservas Biológicas - peso 1.0 (um);

III - Parques Estaduais - peso 0,8 (oito décimos);

IV - Zonas de Vida Silvestre em Áreas de Proteção Ambiental (ZVS em APA's) - peso 0,5 (cinco décimos);

V - Reservas Florestais - peso 0,2 (dois décimos);

VI - Áreas de Proteção Ambiental (APA's) - peso 0,1 (um décimo);

VII - Áreas Naturais Tombadas - peso 0,1 (um décimo)."

Pode-se verificar que, em relação às Unidades de Conservação, a legislação do Estado de São Paulo prevê beneficiar os municípios que possuem seus territórios integrando Unidades de Conservação criadas pelo Estado, não considerando as áreas criadas e geridas por outros níveis de gestão. Fixa, ainda, as categorias de manejo passíveis de gerar os benefícios, deixando de fora as Reservas Particulares do Patrimônio Natural. Além disso, a Lei não utiliza variáveis ligadas à avaliação da qualidade das Unidades de Conservação, o que, de outra forma, possibilitaria melhor aproveitamento do mecanismo em favor da consolidação das Unidades de Conservação, a exemplo do que acontece no Paraná. ${ }^{81}$

\subsubsection{Minas Gerais}

O Estado de Minas Gerais implantou o ICMS Ecológico através da Lei 12.040/95, posteriormente revogada pela Lei 13.803, de 27 de dezembro de 2000 .

81 LOUREIRO, Wilson. O ICMS biológico na biodiversidade. Disponível em $<$ http://www.universoverde.com.br/indexa/inicio.htm $>$. Acesso em 30 mar. 2005. 
O sistema adotado é bastante analítico e diferenciado, abordando um grande número de variáveis e beneficiando com o repasse inclusive municípios específicos, em razão de sua recente instalação.

Ponto interessante a ser destacado é a forma gradativa como os percentuais de repasse relativos a cada critério foram modificados ao longo de um período inicial de adaptação. A Lei 12.040/95 dispôs sobre os exercícios financeiros de 1997 a 2000, prevendo valores diferenciados para cada ano. Já a Lei 13.803/2000 estabeleceu os valores, também diferenciados, para os exercícios de 2001 a 2005, e, além disso, determinou valores fixos para o ano de 2005 em diante.

Quanto ao critério "Meio Ambiente", a Lei 13.803/2000 determina que deverá ser repassado o valor correspondente a $1 \%$ da parcela a que os municípios têm direito. No que tange a esse critério, que é o ponto principal do presente estudo, a legislação estadual estabelece duas formas de enquadramento dos municípios, para que se beneficiem de maior parcela do ICMS:

1. Saneamento Ambiental - deve o município atender a pelo menos um dos seguintes requisitos:

a) possuir sistema de tratamento ou disposição final de resíduos sólidos urbanos (lixo), que atenda a pelo menos $70 \%$ da população urbana do município, com operação licenciada pelo Conselho Estadual de Política Ambiental - COPAM, sendo que o valor máximo a ser atribuído a cada município não excederá o seu investimento, estimado com base na população atendida e no custo médio per capita dos sistemas de aterro sanitário ${ }^{82}$ e usina de compostagem ${ }^{83}$ de lixo;

\footnotetext{
${ }^{82}$ Aterro sanitário é uma forma de disposição final de resíduos sólidos que obedece a um conjunto de normas operacionais e critérios técnicos, de modo a evitar riscos à saúde pública e ao ambiente. Os resíduos são depositados em terrenos impermeabilizados e a seguir compactados e recobertos por
} 
b) possuir sistema de tratamento de esgotos sanitários, que atenda a pelo menos $50 \%$ da população urbana do município, com operação licenciada pelo COPAM, sendo que o valor máximo a ser atribuído a cada município não excederá o seu investimento, estimado com base na população atendida e no custo médio per capita das estações de tratamento de esgotos sanitários.

2. Unidades de Conservação - objetivando compensar os municípios que possuem partes de seus territórios protegidas por unidades de conservação federais, estaduais ou municipais e, inclusive, particulares, definidas na lei e cadastradas junto à Secretaria de Meio Ambiente e Desenvolvimento Sustentável - SEMAD, com limites territoriais definidos e com restrição de uso do solo, e para incentivar a criação, implantação e manutenção de unidades de conservação pelos próprios municípios, são estes também beneficiados.

O valor do repasse, limitado ao percentual estabelecido em lei para o critério "Meio Ambiente", será diretamente proporcional ao nível de adequação dos municípios aos critérios fixados: $50 \%$ com base no saneamento ambiental e $50 \%$ com base nas unidades de conservação.

Outro critério adotado é o do patrimônio cultural que, de acordo com a Lei 13.803/2000, deverá representar $1 \%$ do valor a ser repassado aos municípios.

\footnotetext{
camadas de terra. Deve haver dispositivos para drenagem superficial da área, captação e tratamento de chorume (líquido de alto potencial poluidor proveniente da decomposição da matéria orgânica presente no lixo) e captação e tratamento dos gases provenientes da decomposição do lixo (principalmente metano e dióxido de carbono). Um aterro sanitário deve contar com monitoramento ambiental e geotécnico permanente, além de um plano de encerramento de suas atividades. (MOUSINHO, Patrícia. Glossário. p. 333-367. in TRIGUEIRO, André (coord.). Meio Ambiente no Século 21: 21 especialistas falam da questão ambiental nas suas áreas de conhecimento. $2^{\mathrm{a}}$ ed. Rio de Janeiro: Sextante, 2003.)

${ }^{83}$ Compostagem é a decomposição, por microorganismos aeróbicos, da matéria orgânica contida em restos animais ou vegetais. O material resultante do processo, chamado de composto, é utilizado na adubação do solo. (MOUSINHO, Patrícia. Glossário. p. 333-367. in TRIGUEIRO, André (coord.). Meio Ambiente no Século 21: 21 especialistas falam da questão ambiental nas suas áreas de conhecimento. $2^{\mathrm{a}}$ ed. Rio de Janeiro: Sextante, 2003.)
} 
O Estado de Minas não adotou variáveis qualitativas para o cálculo dos índices que os municípios têm direito a receber, perdendo, assim, a oportunidade de utilizar mais efetivamente o ICMS Ecológico em benefício da consolidação das unidades de conservação.

\title{
3.2.4.4. Rondônia
}

Rondônia implantou o ICMS Ecológico através da Lei Complementar 147, de 15 de janeiro de 1996. A porcentagem a ser distribuída segundo o critério ambiental será de 5\% (cinco por cento), que serão proporcionais à ocupação territorial dos municípios com unidades de conservação.

$\mathrm{O}$ artigo $3^{\circ}$ da LC 147/96 estabelece que:

\begin{abstract}
"Art. $3^{\circ}$ - As unidades de conservação de que trata a alínea "e" do inciso II, do art. $1^{\circ}$, são áreas protegidas e estabelecidas em ecossistemas significativos do território estadual no âmbito administrativo do governo Federal, Estadual e Municipal, nas categorias de Estação Ecológica, Reserva Biológica, Parque, Monumento Natural, Área de Proteção Ambiental, Reserva Indígena, Floresta, Reserva Extrativista e outras inclusas em quaisquer categorias de unidade de conservação, criadas por Leis ou decretos municipal, estadual ou federal."
\end{abstract}

Assim, observa-se que o ICMS Ecológico adotado por este Estado está calcado no critério ligado às unidades de conservação e terras indígenas. Outro aspecto importante da LC 147/96 diz respeito à possibilidade de redução do ICMS Ecológico dos municípios cujas unidades de conservação sofram invasões ou outros tipos de agressões, como pode ser verificado pela leitura do artigo $5^{\circ}$, caput e parágrafo único:

“Art. $5^{\circ}$ - O órgão responsável pelo gerenciamento da política estadual de meio ambiente, em parceria com outras instituições que possuam atribuições correlatas adotará um sistema de cadastramento das unidades de conservação municipais, estaduais e federais, de modo que lhe permita conhecer o nível de agressão sofrida por invasões ou explorações ilegais. 
Parágrafo único - Serão aplicados redutores nos cálculos dos percentuais de participação dos municípios na repartição do Imposto sobre operações relativas à circulação de mercadorias a prestação de serviços de transporte interestadual e intermunicipal e de comunicação - ICMS, em função da comprovação de invasões ou explorações ilegais, repartindo-se o montante reduzido entre aqueles municípios cujas unidades de conservação esteja em acordo com a legislação ambiental."

Rondônia também não adota o critério qualitativo e, na mesma linha de Minas Gerais, perde a oportunidade de incrementar o processo de regularização, planejamento, implementação e manutenção das unidades de conservação, além da busca, via ICMS Ecológico, da melhoria da qualidade de vida dos povos indígenas.

\subsubsection{Amapá}

O Amapá aprovou o ICMS Ecológico através da Lei Estadual 322, de 23 de dezembro de 1996, no contexto de uma reforma nos critérios de repasse. Fez uma ampla reforma nos critérios de rateio do ICMS, a exemplo do Estado de Minas Gerais. Em relação às unidades de conservação, segue o modelo de cálculo dos índices realizados no Paraná. Além disso, adota também o critério patrimônio cultural.

"Art. $2^{\circ}$ - As parcelas de receita de que tratam os incisos II e III deste artigo serão creditadas segundo os critérios a seguir:

I - 3/4 (três quartos) na proporção do Valor Adicionado, nas operações relativas à Circulação de Mercadorias e sobre a Prestação de Serviços;

II - 1/4 (um quarto) será distribuído nos percentuais e nos exercícios do Anexo I desta Lei conforme os seguintes critérios:

(...)

$\S 6^{\circ}$ - patrimônio cultural: relação percentual entre o Índice de Patrimônio Cultural do Município e o somatório dos índices para todos os Municípios, fornecida pela Fundação Estadual da Cultura, que fará publicar até o dia 30 de abril de cada ano, os dados apurados relativos ao ano civil imediatamente anterior, observado o disposto no Anexo III desta Lei:

$\S 7^{\circ}$ - meio ambiente, observado o seguinte: 
a) os recursos serão distribuídos com base no Índice de Conservação do Município, calculado de acordo com o Anexo IV desta Lei, considerando-se as unidades de conservação estaduais, federais e particulares, bem como as unidades municipais que venham a ser cadastradas, observados os parâmetros e os procedimentos definidos pelo órgão ambiental estadual:

b) a Secretaria de Estado de Meio Ambiente fará publicar, até o dia 30 de abril de cada ano os dados apurados relativamente ao ano civil imediatamente anterior, com a relação de Municípios habilitados segundo a alínea anterior."

\subsubsection{Rio Grande do Sul}

Em 1997, foi aprovada no Estado do Rio Grande do Sul a Lei 11.038, que criou, mesmo que não intencionalmente, seu ICMS Ecológico. Associando o critério ambiental ao critério "área do município" define, no inciso III, do artigo $1^{\circ}$ da referida Lei, que deverá ser repartido entre os municípios “7\% (sete por cento) com base na relação percentual entre a área do município, multiplicando-se por 3 (três) as áreas de preservação ambiental e aquelas inundadas por barragens, exceto as localizadas nos municípios sedes das usinas hidrelétricas, e a área calculada do Estado....".

Independentemente de qualquer limitação, os profissionais do órgão ambiental encarregados pelo cumprimento da Lei, têm procurado, com criatividade, tirar o máximo proveito da oportunidade criada pela Lei em favor da consolidação das unidades de conservação, utilizando, além da variável quantitativa, variáveis qualitativas. ${ }^{84}$

\subsubsection{Mato Grosso do Sul}

O Mato Grosso do Sul aprovou o ICMS Ecológico através da Lei Complementar 77/1994, que estabeleceu que 5\% da parcela da receita arrecadada pelo ICMS será distribuída conforme critérios ambientais (unidades

\footnotetext{
${ }^{84}$ LOUREIRO, Wilson. ICMS Ecológico - A consolidação de uma experiência brasileira de incentivo à conservação da biodiversidade. Disponível em <www.floresta.ufpr.br/posgraduacao/seminarios/wilson/ICMS_ecologico_no_brasil.doc>. Acesso em 13.abr.2005
} 
de conservação e mananciais de abastecimento público). Mas esta LC só foi regulamentada em 2000, pela Lei 2.193 e pelo Decreto 10.478, e em 2001 pela Lei 2.259 .

A Lei 2.259/2001 determina que o percentual de 5\% será rateado de forma sucessiva e progressiva, de acordo com os seguintes índices: I - 2\% para o exercício financeiro de 2002; II - 3,5\% para o exercício financeiro de 2003; e III - 5\% para o exercício financeiro de 2004 .

São contemplados os municípios que abrigam em seu território parte ou o todo de unidades de conservação e áreas que sejam por elas diretamente influenciadas, as áreas de terras indígenas e os mananciais de abastecimento público.

Constituem-se fundamentos do processo de cálculo do ICMS Ecológico, procedimentos de caráter quantitativo e qualitativo em relação às unidades de conservação e outras áreas especialmente protegidas, sendo que, para efeito da execução dos cálculos para a composição dos índices devidos aos municípios para o exercício de 2002, foram utilizados apenas os procedimentos quantitativos.

É importante mencionar que "não será realizado crédito aos municípios por qualquer tipo de porção territorial com área degradada", conforme dispõe o artigo $9^{\circ}$ do Decreto 10.478/2000.

Como critério fundamental para avaliação da qualidade das unidades de conservação, o artigo 11 do Decreto 10.478/2000 determina que deverão ser levadas em conta ações empreendidas pelos municípios contemplados em relação à melhoria da conservação da unidade de conservação, independente do âmbito de gestão da área, sendo essencial a edição de legislação municipal para regular a matéria.

A operacionalização do mencionado critério poderá ser consubstanciada em Termos de Compromisso firmados pelos municípios e anuídos por parceiros intervenientes interessados na conservação da biodiversidade, como 
o Ministério Público, Organizações não Governamentais, Universidades, entre outros.

\subsubsection{Mato Grosso}

O Estado do Mato Grosso, a exemplo do Mato Grosso do Sul, está fazendo a implementação do ICMS Ecológico, aprovado pela Lei Complementar 73, em 7 de dezembro de 2000, de forma gradual, ou seja, num primeiro momento pelo critério apenas quantitativo e, numa segunda etapa, está prevista a implantação dos critérios qualitativos. Embora utilizando terminologias diferentes, a Lei adota os mesmos procedimentos para os cálculos dos percentuais a que os municípios têm direito que aqueles utilizados no Estado do Paraná. ${ }^{85}$

$\mathrm{O}$ artigo $2^{\circ}$ da LC $73 / 2000$ estabelece os percentuais que serão destinados a cada um dos critérios:

"Parágrafo único. Os percentuais correspondentes aos critérios de distribuição da parcela do ICMS referida no caput deste artigo serão assim definidos:

\begin{tabular}{|l|r|r|r|}
\hline \multirow{2}{*}{ Critérios } & \multicolumn{3}{|c|}{ Percentuais por exercício físcal } \\
\cline { 2 - 4 } & $\mathbf{1}^{\mathbf{0}}$ ano & $\mathbf{2}^{\mathbf{0}}$ ano & $\mathbf{3}^{\mathbf{0}}$ ano \\
\hline Receita Própria & $8,0 \%$ & $8,0 \%$ & $6,0 \%$ \\
\hline População & $2,0 \%$ & $2,0 \%$ & $2,0 \%$ \\
\hline Área do Município & $1,0 \%$ & $1,0 \%$ & $1,0 \%$ \\
\hline Cota Igual & $9,0 \%$ & $9,0 \%$ & $9,0 \%$ \\
\hline Saneamento Ambiental & $\mathbf{0 , 0 \%}$ & $\mathbf{0 , 0} \%$ & $\mathbf{2 , 0} \%$ \\
\hline Unidade de Conservação/Terra Indígena & $\mathbf{5 , 0 \%}$ & $\mathbf{5 , 0} \%$ & $\mathbf{5 , 0} \%$ \\
\hline
\end{tabular}

${ }^{85}$ LOUREIRO, Wilson. ICMS Ecológico - A consolidação de uma experiência brasileira de incentivo à conservação da biodiversidade. Disponível em <www.floresta.ufpr.br/posgraduacao/seminarios/wilson/ICMS_ecologico_no_brasil.doc>. Acesso em 13.abr.2005 


\begin{tabular}{|l|r|r|r|}
\hline Soma & $25,0 \%$ & $25,0 \%$ & $25,0 \%$ \\
\hline
\end{tabular}

Para o cálculo do critério Saneamento Ambiental, o artigo $7^{\circ}$ da LC 73/2000 estabelece que deverão ser observados os Sistemas de Captação, Tratamento e Distribuição de Água, Sistemas de Coleta, Tratamento e Disposição Final de Resíduos Sólidos e Sistemas de Esgotamentos Sanitários nos Municípios.

A Fundação Estadual do Meio Ambiente (FEMA) deverá publicar, anualmente, a lista dos Municípios habilitados a receberem a cota parte referente ao critério Saneamento Ambiental, a partir do segundo exercício fiscal da vigência da LC 73/2000. Assim, a parcela referente a este critério será calculada e distribuída a partir do terceiro exercício fiscal. No período da não vigência da distribuição da parcela referente ao Saneamento Ambiental, a mesma será calculada e distribuída 100\% (cem por cento) de acordo com o critério Receita Própria.

Conforme o artigo $8^{\circ}$ da LC 73/2000, o critério Unidade de Conservação/Terra Indígena deverá ser calculado através da relação percentual entre o índice de Unidades de Conservação dos Municípios e a soma dos índices de Unidades de Conservação de todos os Municípios do Estado, considerando-se as unidades de conservação Municipais, Estaduais e Federais cadastradas e aquelas que venham a ser cadastradas, inclusive Áreas Indígenas, observados os parâmetros e os procedimentos definidos pelo Órgão Ambiental Estadual e Federal.

O Órgão Ambiental Estadual deverá publicar, anualmente, lista atualizada das Unidades de Conservação/Terras Indígenas e dos Municípios habilitados a receber a cota parte referente a este critério.

No caso de grave dano ambiental, o Órgão Ambiental Estadual poderá, após vistoria, impor temporariamente uma redução percentual do Fator de 
Conservação de Unidades de Conservação - FCU de uma determinada Unidade de Conservação.

\subsubsection{Pernambuco}

No Estado de Pernambuco o ICMS Ecológico é denominado de "ICMS Sócio-Ambiental". Foi aprovado pela Lei Estadual 11.899, de 21 de dezembro de 2000 , e destina $12 \%$ (doze por cento) da receita do ICMS, a partir do ano 2003, considerando aspectos sócio-ambientais. Destes $12 \%$ relativos aos critérios sócio-ambientais, $1 \%$ vai para os municípios que possuem unidades de conservação e 5\% devem ser distribuídos de forma igualitária aos municípios que possuam unidade de compostagem ou aterro sanitário controlado.

Neste Estado, embora a Lei defina que os critérios para rateio do ICMS devam ser implementados em sua grande maioria a partir de 2003, o Decreto Estadual 23.473 objetiva a implementação quase que total da Lei do ICMS Sócio-ambiental a partir de 2002, tendo como ano de apuração o ano 2001.

\subsubsection{Tocantins}

O Estado do Tocantins, através da Lei 1.323, de 4 de abril de 2002, introduziu o ICMS Ecológico a partir do exercício de 2003. Com esta Lei são adotados critérios que incentivam os municípios a: criar leis, decretos e dotações orçamentárias que resultem na estruturação e implementação da Política Municipal de Meio Ambiente e da Agenda 21 local; abrigar unidades de conservação ambiental, inclusive terras indígenas; controlar queimadas e combater incêndios; promover: a) a conservação e o manejo do solo; b) o saneamento básico; c) a conservação da água; d) a coleta e destinação do lixo. 
O cálculo da parcela do produto da arrecadação do ICMS pertencente aos municípios fica a cargo do Instituto Natureza do Tocantins NATURATINS, quanto aos índices: a) política Municipal de Meio Ambiente; b) Unidades de Conservação, inclusive Terras Indígenas; c) controle de queimadas, combate a incêndios; d) saneamento básico; e) conservação da água; f) coleta e destinação do lixo; e do Instituto de Desenvolvimento Rural do Estado do Tocantins - RURALTINS, quanto ao índice Conservação e Manejo do Solo.

Os índices que ficam a cargo do NATURATINS serão determinados segundo os critérios de: participação pública no planejamento e gestão das ações; avaliação da qualidade; educação ambiental; desenvolvimento do ecoturismo, quando for o caso; aplicação dos recursos em matéria de meio ambiente repassados ao município.

Assim como nos outros Estados que adotam o ICMS Ecológico, na existência, num mesmo município, de sobreposição de diferentes unidades de conservação ou de unidades de conservação e terras indígenas, adotar-se-á o índice que representar maior retorno financeiro ao município.

O Anexo Único à Lei 1.323/2002 estabelece a percentagem, que será progressiva, em que cada critério será considerado na distribuição da parcela do ICMS pertencente aos municípios. Vejamos a tabela ${ }^{86}$ abaixo:

\begin{tabular}{|l|l|l|l|l|l|}
\hline \multirow{2}{*}{ Critérios } & \multicolumn{6}{|l|}{ Ano de Implantação / Índices de Cálculos } \\
\cline { 2 - 6 } & $\mathbf{2 0 0 3}$ & $\mathbf{2 0 0 4}$ & $\mathbf{2 0 0 5}$ & $\mathbf{2 0 0 6}$ & $\mathbf{2 0 0 7}$ \\
\hline Valor Adicionado & 82,5 & 80,2 & 78,9 & 75,6 & 75,0 \\
\hline Quota Igual & 9,0 & 8,5 & 8,0 & 8,0 & 8,0 \\
\hline $\begin{array}{l}\text { Número de } \\
\text { Habitantes }\end{array}$ & 2,5 & 2,4 & 2,3 & 2,2 & 2,0 \\
\hline Área Territorial & 2,5 & 2,4 & 2,3 & 2,2 & 2,0 \\
\hline $\begin{array}{l}\text { Política Municipal } \\
\text { do Meio } \\
\text { Ambiente }\end{array}$ & $\mathbf{0 , 5}$ & $\mathbf{1 , 0}$ & $\mathbf{1 , 5}$ & $\mathbf{2 , 0}$ & $\mathbf{2 , 0}$ \\
\hline
\end{tabular}

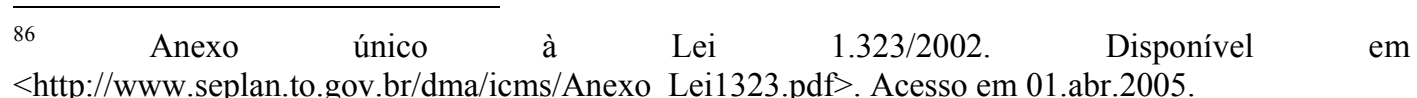




\begin{tabular}{|l|l|l|l|l|l|}
\hline $\begin{array}{l}\text { Unidades de } \\
\text { Conservação e } \\
\text { Terras Indígenas }\end{array}$ & 1,0 & 1,5 & 2,0 & 2,5 & 3,5 \\
\hline $\begin{array}{l}\text { Controle e } \\
\text { Combate a } \\
\text { Queimadas }\end{array}$ & 0,5 & 1,5 & 1,5 & 2,0 & 2,0 \\
\hline $\begin{array}{l}\text { Saneamento } \\
\text { Básico, } \\
\text { Conservação da } \\
\text { Água e Coleta e } \\
\text { Destinação do } \\
\text { Lixo }\end{array}$ & 1,0 & 1,5 & 2,0 & 3,5 & 3,5 \\
\hline $\begin{array}{l}\text { Conservação dos } \\
\text { Solos }\end{array}$ & 0,5 & 1,0 & 1,5 & 2,0 & 2,0 \\
\hline Total & 100,00 & 100,00 & 100,00 & 100,00 & 100,00 \\
\hline
\end{tabular}

Pode-se observar que, levando-se em consideração a soma de todos os critérios ambientais (marcados em negrito), o percentual definido pela Lei $1.323 / 2002$ é de: $3,5 \%$ para o ano de $2003 ; 6,5 \%$ para $2004 ; 8,5 \%$ para 2005 ; 12\% para 2006; e 13\% para 2007. De longe, é o maior até hoje estabelecido em relação a todos os outros estados brasileiros.

A Lei 1.323/2002 foi regulamentada pelo Decreto 1.666, de 26 de dezembro de 2002, e também pela Resolução 2, de 4 de novembro de 2003, do COEMA. Esta legislação prevê que o cálculo da parcela do ICMS pertencente aos municípios obedecerá a critérios quantitativos e qualitativos.

Em relação à política municipal de meio ambiente, o critério qualitativo levará em consideração a elaboração legislativa e o cumprimento da legislação específica; já o critério quantitativo observará a dotação orçamentária realizada. No caso das unidades de conservação e terras indígenas, o critério qualitativo seguirá as propostas do NATURATINS aprovadas pelo Conselho Estadual de Meio Ambiente - COEMA; e o quantitativo, as categorias e grupos definidos nos Anexos I e II ao Decreto 1.666/2002; também será observada a superfície das respectivas áreas.

Quanto ao controle e combate de queimadas, os critérios qualitativos serão a organização e a manutenção de brigadas civis de combate a queimadas 
e incêndios florestais e práticas de educação ambiental; e o critério quantitativo será pelo número de focos de calor registrados, conforme dados do Instituto Nacional de Pesquisas Espaciais -INPE, e a superfície municipal.

No que tange ao saneamento básico, conservação da água, coleta e destinação do lixo, o critério qualitativo levará em conta: a) o índice de qualidade da água - IQA, composto por variáveis propostas pelo NATURATINS e aprovadas pelo COEMA; b) a execução de ações voltadas para a educação ambiental e sanitária; c) a disposição final adequada de lixo. Em relação ao critério quantitativo, o número de domicílios atendidos com água potável tratada, banheiro ou sanitário, sistema de coleta de lixo, e a superfície e estado de conservação das matas ciliares existentes, em relação às exigências legais.

Em se tratando da conservação dos solos, os critérios qualitativos serão determinados com base em programas e projetos que visem: a) à utilização dos solos conforme sua aptidão; b) ao uso de agrotóxicos com receituário agronômico e o descarte adequado das embalagens; c) à implementação de práticas mecânicas e vegetativas de conservação e manejo compatíveis com as características dos respectivos solos. Para o quantitativo, serão observados os percentuais de superfície municipal cultivada e não conservada e a devidamente cultivada.

$\mathrm{O}$ artigo $3^{\circ}$ do Decreto estabelece que, no ano de apuração de 2003, exercício civil de 2004, o cálculo dos índices levará em consideração apenas os parâmetros quantitativos, a fim de possibilitar a capacitação dos municípios, com exceção do parâmetro relativo às matas ciliares, que será incorporado no ano de apuração 2004.

Já o artigo $4^{\circ}$ prevê que, até o ano de apuração de 2004, ano civil de 2005, o índice relativo ao critério de conservação dos solos será distribuído de forma eqüitativa entre os municípios, sem considerar os parâmetros qualitativos e quantitativos. 
Ainda de acordo com o Decreto, não são consideradas, para efeito de crédito, as áreas degradadas, ainda que em áreas protegidas, exceto no caso de estarem em processo de recuperação, desde que haja plano aprovado pelo órgão ambiental. Além disso, podem ser descontadas do número de focos de incêndio as queimadas controladas, em consonância com o disposto no Decreto Federal 2.661, de 08 de julho de 1998.

\subsubsection{Alguns resultados obtidos com a experiência do ICMS Ecológico}

Em 1995, o ICMS Ecológico foi considerado pela IUCN (International Union for the Conservation of Nature and Natural Resources ${ }^{87}$ uma das sete experiências com êxito, para a conservação da biodiversidade, na América Latina e no Caribe, pós Rio-92. ${ }^{88}$

Em 1996, foi considerado pela Fundação Getúlio Vargas, uma das 100 experiências mais importantes em administração pública no Brasil. No mesmo ano, o Ministério do Meio Ambiente a elegeu uma das 100 experiências exitosas em gestão ambiental para o desenvolvimento sustentável, na Rio +5 . No ano seguinte, ganhou o prêmio Henry Ford de Conservação Ambiental, na Categoria "Negócios em Conservação" organizado pela Conservation International do Brasil, com apoio da Ford do Brasil Ltda. ${ }^{89}$

Senise Zeola observa que:

\footnotetext{
"As experiências com o ICMS Ecológico têm demonstrado que se trata de uma medida positiva, principalmente em relação à conscientização sobre a conservação ambiental. Os Municípios já conseguem perceber as unidades de conservação como uma oportunidade de gerar renda, não como um empecilho ao desenvolvimento. A perspectiva de ampliar a receita
}

\footnotetext{
${ }^{87}$ União Internacional para a Conservação da Natureza e dos Recursos Naturais (tradução livre).

${ }^{88}$ Disponível em <http://www.pr.gov.br/meioambiente/iap/bio_icms.shtml >. Acesso em 30.mar.2005.

${ }^{89}$ Disponível em < http://www.pr.gov.br/meioambiente/iap/bio_icms.shtml $>$. Acesso em 30.mar.2005.
} 
advinda do ICMS Ecológico estimula os Municípios a investir na conservação." ${ }^{90}$

No caso do Paraná, "além de resultados indiretos, mas de significativa importância, tais como: o aprimoramento institucional do IAP, a democratização do debate sobre as unidades de conservação, a justiça fiscal pela conservação, a construção dos corredores da biodiversidade, geração de trabalho e renda e possibilidade da reprodução em outros estados, os resultados mais significativos e contundentes dizem respeito ao aumento da superfície de áreas protegidas e evolução da qualidade da gestão das unidades de conservação."91

Conforme a tabela abaixo ${ }^{92}$, observa-se que houve uma evolução de 159,77\% no aumento de superfície das áreas protegidas:

Evolução da superfície das unidades de conservação e outras áreas especialmente protegidas, no Estado do Paraná, até 1991 e de 1992 até 2001 (em hectares) registradas e passíveis de oferecer crédito do ICMS Ecológico aos respectivos municípios

\begin{tabular}{l|r|r|r}
\hline \multicolumn{1}{c|}{ NÍVEL DE GESTÃO } & ATÉ 1991 & DE 1992 A 2001 & $\begin{array}{r}\text { EVOLUÇÃO } \\
(\%)\end{array}$ \\
\hline Federal & $584.622,98$ & $694.186,26$ & 18.74 \\
Estadual & $118.163,59$ & $964.554,92$ & 716,28 \\
Municipal & $8.485,50$ & $226.674,89$ & $2.462,60$ \\
Terras indígenas & $81.500,74$ & $83.245,44$ & 2,14 \\
RPPN federal & 0,0 & $1.706,13$ & - \\
RPPN estadual & 0,0 & $33.154,72$ & - \\
Faxinais & 0,0 & $18.927,11$ & - \\
Áreas de Preservação Permanente & 0,0 & $17.107,69$ & - \\
Reserva Legal & 0,0 & $16.697,73$ & - \\
Sítios Especiais & 0,0 & $1.101,56$ & - \\
Outras Florestas de conexão & 0,0 & $3.245,62$ & - \\
TOTAL & $794.763,81$ & $2.064 .594,07$ & 159,77 \\
\hline
\end{tabular}

\footnotetext{
${ }^{90}$ ZEOLA, Senise Freire Chacha. ICMS - Instrumento de Proteção e Conservação do Meio Ambiente. Revista de Direito Ambiental. São Paulo, n. 30, p. 179-197.

91 LOUREIRO, Wilson. O ICMS Ecológico na Biodiversidade. Disponível em $<$ http://pinho.floresta.ufpr.br/pos-graduacao/seminarios/wilson/ICMS_ecologico_no_parana.doc>. Acesso em 5.5.2005.

92 LOUREIRO, Wilson. O ICMS Ecológico na Biodiversidade. Disponível em $<$ http://pinho.floresta.ufpr.br/pos-graduacao/seminarios/wilson/ICMS_ecologico_no_parana.doc>. Acesso em 5.5.2005.
} 
FONTE: DEBIO/DIBAP/IAP - ICMS Ecológico por Biodiversidade.

Nota: As Áreas de Preservação Permanente, as Reservas Legais, os Sítios Especiais e as Outras Florestas de conexão, só são consideradas nos entornos das Unidades de Conservação de uso indireto, através da realização de procedimentos técnicos e administrativos especiais.

Como conseqüência natural do aumento de superfície das áreas protegidas, as unidades de conservação começaram a ligar-se umas às outras, formando corredores ecológicos. ${ }^{93}$

"Talvez uma das contribuições mais promissoras do ICMS Ecológico esteja sendo a busca da construção dos corredores de biodiversidade, malhas ou mosaicos de conservação, que é como se denominam os modelos de gestão da conexão de fragmentos vegetais, com vistas à criação de condições à reprodução e à recolonização da vida silvestre." 94

Além da evolução quantitativa demonstrada na tabela acima, houve também uma melhora qualitativa na conservação dos Parques estaduais, como se verifica a partir do gráfico ${ }^{95}$ que se segue. Pode-se observar que entre os anos 1999 e 2000 houve pequena variação. Na opinião do pesquisador do IAP, Wilson Loureiro, essa variação foi ocasionada pela alteração parcial no processo de avaliação, ou seja, a partir de 2000 esta avaliação passou a ser realizada diretamente pelo gerente da unidade de conservação, não mais pelo técnico do Escritório Regional do IAP. Para ele, a avaliação feita pelo gerente, não apenas como interlocutor, mas como sujeito, pode representar um avanço nos procedimentos, pois sentindo de maneira mais forte os problemas para

\footnotetext{
${ }^{93}$ Disponível em $<$ http://www.carbonobrasil.com/noticias.asp?iNoticia=6542\&iTipo=18\&idioma=1 $>$. Acesso em 30.mar.2005.

${ }^{94}$ LOUREIRO, Wilson. Contribuição do ICMS Ecológico à Conservação da Biodiversidade no Estado do Paraná. Tese de Doutorado apresentada ao Curso de Pós-Graduação em Engenharia Florestal da Universidade Federal do Paraná. Curitiba, 2002. Disponível em $<$ http://pinho.floresta.ufpr.br/pos-graduacao/seminarios/wilson/contribuicao_do_icms.pdf $>$. Acesso em 5.mai.2005.

$95 \quad$ LOUREIRO, Wilson. Disponível em $\quad<\mathrm{http}$ ://pinho.floresta.ufpr.br/pos-
} graduacao/seminarios/wilson/ICMS ecologico no parana.doc>. Acesso em 5.mai.2005 
gestão da área, tem a tendência de ser mais rigoroso, o que deve ser um desafio para otimização do instrumento de política. ${ }^{96}$

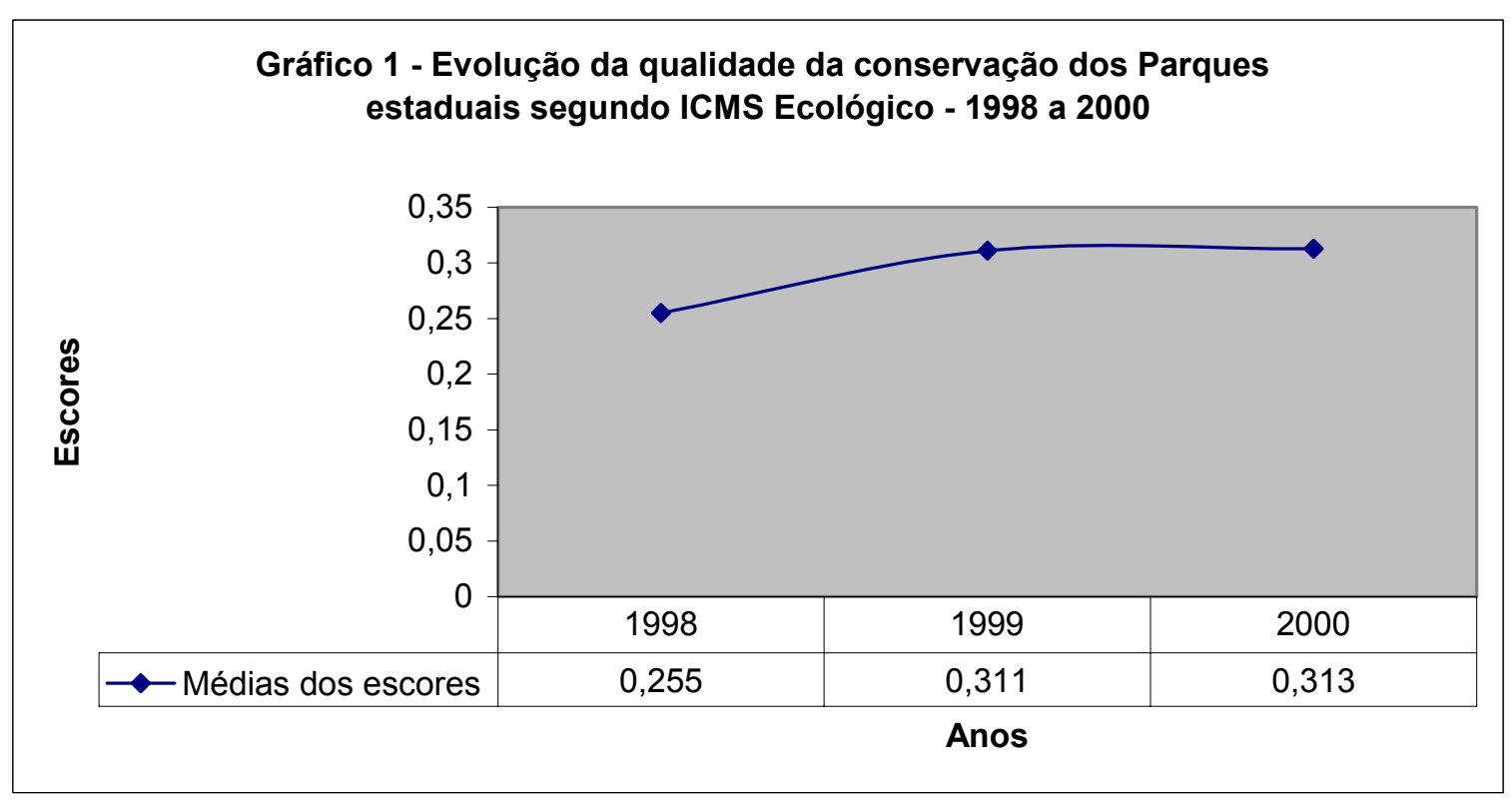

$\mathrm{O}$ número de municípios paranaenses beneficiados pelo ICMS Ecológico cresceu de 112 em 1992, para 192 em 1998, ou seja, 48,12\% dos municípios do Estado. $^{97}$

Muitos desses municípios, contendo espaços especialmente protegidos, dependem significativamente do ICMS Ecológico. O impacto do critério ambiental no repasse total de recursos do ICMS, chegou a variar de $82 \%$ a $28 \%$ no primeiro trimestre de $1998 .{ }^{98}$ Alguns passaram até a ser dependentes desses recursos, incluindo-se no rol dos chamados "municípios ecológicos". 99

96 LOUREIRO, Wilson. Disponível em $<$ http://pinho.floresta.ufpr.br/posgraduacao/seminarios/wilson/ICMS_ecologico_no_parana.doc $>$. Acesso em 5.mai.2005

${ }_{97}$ CAMPOS, Léo Pompeu de Rezende. ICMS ecológico: experiências nos estados do Paraná, São Paulo, Minas Gerais e alternativas na Amazônia. Disponível em $<$ http:// www.mma.gov.br/port/sds/index.cfm>. Acesso em 11.mai.2005.

${ }^{98}$ CAMPOS, Léo Pompeu de Rezende. ICMS ecológico: experiências nos estados do Paraná, São Paulo, Minas Gerais e alternativas na Amazônia. Disponível em $<\mathrm{http} / /$ www.mma.gov.br/port/sds/index.cfm>. Acesso em 11.mai.2005.

99 LOUREIRO, Wilson. Contribuição do ICMS Ecológico à Conservação da Biodiversidade no Estado do Paraná. Tese de Doutorado apresentada ao Curso de Pós-Graduação em Engenharia Florestal da Universidade Federal do Paraná. Curitiba, 2002. Disponível em 
No Estado de São Paulo,

\begin{abstract}
“o número de municípios beneficiados elevou-se de 104, em 1994, para 152 em 1999; correspondendo, neste ano, a 23,56\% dos municípios do Estado, quando o valor distribuído via ICMS Ecológico atingiu cerca de 27 milhões de reais. Na região de Ribeira do Iguape, o valor repassado sob esse critério superou o correspondente ao VAF. Trata-se de uma região classificada como de conservação, em que todos os 23 municípios abrigam territórios especialmente protegidos. O litoral norte, também uma região com características de conservação, recebe o segundo maior repasse pelo ICMS Ecológico. (Secretaria do Meio Ambiente, São Paulo, 1998).",100
\end{abstract}

Em Minas Gerais, o número de unidades de conservação passou de 65 para 135 em 1998. O aumento em área preservada foi de $48 \%$ e o número de municípios beneficiados aumentou de 101 no início de 1996 para 172 em 1998. $^{101}$

O consorciamento e a cooperação entre municípios vizinhos para resolverem problemas de lixo vêm sendo estimulados pelo ICMS Ecológico, como ocorreu com Ipatinga e Caratinga, que celebraram acordo que beneficia a ambos os municípios. Também os municípios de João Monlevade, Bela Vista de Minas e Rio Piracicaba se uniram para a implantação de um aterro sanitário. $^{102}$

De acordo com o critério unidades de conservação, foram distribuídos R\$ 7,063 milhões no ano de 1999. No primeiro ano, 1996, foram beneficiados 98 municípios, caracterizando 14\% dos municípios do Estado. Naquele ano,

\footnotetext{
$<$ http://pinho.floresta.ufpr.br/pos-graduacao/seminarios/wilson/contribuicao_do_icms.pdf $>$. Acesso em 5.mai.2005.

${ }^{100}$ CAMPOS, Léo Pompeu de Rezende. ICMS ecológico: experiências nos estados do Paraná, São Paulo, Minas Gerais e alternativas na Amazônia. Disponível em $<\mathrm{http} / / /$ www.mma.gov.br/port/sds/index.cfm>. Acesso em 11.mai.2005.

$101 \quad$ Disponível em

$<$ http://www.ambientetotal.pro.br/icmseco.html+\%22icms+ecol\%C3\%B3gico\%22+paran\%C3\%A1\&h $\mathrm{l}=\mathrm{pt}-\mathrm{BR} \& \mathrm{lr}=$ lang $\mathrm{pt}>$. Acesso em 30.mar.2005

${ }_{102}$ RIBEIRO, Maurício Andrés; LOPES, Ana Lúcia Bahia; e RODRIGUES, Ludmila Alves (da Fundação Estadual do Meio Ambiente de Minas Gerais - FEAM) Disponível em $<$ http://www.unilivre.org.br/banco_de_dados/experiencias/experiencias/140.html $>$ Acesso em 30.mar.2005.
} 
foram consideradas unidades federais e estaduais, existentes em 1995, previamente cadastradas pelo órgão ambiental estadual e que viabilizaram a distribuição dos recursos por número expressivo de municípios com restrita atividade econômica. A partir de 1996, as unidades de conservação municipais passaram a ser cadastradas. Em 1999, o número de municípios beneficiados cresceu para 197 , representando $28 \%$ das municipalidades mineiras. ${ }^{103}$

Entre os anos de 1996 e 1999, a superfície de áreas protegidas institucionalizadas em Minas Gerais foi ampliada em um milhão de hectares, cerca de $90 \%$ de acréscimo, como indica a tabela ${ }^{104}$ abaixo:

Minas Gerais: evolução da superfície das unidades de conservação e outras áreas protegidas, de 1995 a 1999 (setembro) - em hectares.

\begin{tabular}{lrrr}
\hline NíVEL DE GESTÃO & 1995 & 1999 & EVOLUÇÃO \\
\hline Federal & 777.271 & 749.606 & $-3,56 \%$ \\
Estadual & 322.155 & 1.152 .292 & $257,68 \%$ \\
Municipal & 6.887 & 126.448 & $1.736,00 \%$ \\
Terras indígenas & 59.359 & 59.359 & - \\
RPPN federal & 20.258 & 26.413 & $30,38 \%$ \\
RPPN estadual & - & 5.584 & $100,00 \%$ \\
Total & 1.116 .130 & 2.119 .702 & $89,91 \%$ \\
\hline
\end{tabular}

FONTE: Cadastro de unidades de conservação: Resoluções no 3, de 27.12.95 e no 39, de 30.12.99, da Secretaria de Meio Ambiente e Desenvolvimento Sustentável - SEMAD.

No que tange ao critério saneamento ambiental, nenhum município foi contemplado no primeiro ano de aplicação da Lei (1996). Mas logo no ano seguinte o município de Betim se habilitou pelo sistema de saneamento (aterro sanitário e usina de compostagem), recebendo, a partir de setembro, recursos do ICMS Ecológico, tendo sido o investimento na implantação destes sistemas

103 CAMPOS, Léo Pompeu de Rezende. ICMS ecológico: experiências nos estados do Paraná, São Paulo, Minas Gerais e alternativas na Amazônia. Disponível em $<$ http:// www.mma.gov.br/port/sds/index.cfm>. Acesso em 11.mai.2005.

${ }^{104}$ CAMPOS, Léo Pompeu de Rezende. ICMS ecológico: experiências nos estados do Paraná, São Paulo, Minas Gerais e alternativas na Amazônia. Disponível em $<$ http:// www.mma.gov.br/port/sds/index.cfm>. Acesso em 11.mai.2005. 
recuperado em apenas um ano. ${ }^{105}$ Com a construção do aterro sanitário a cidade já recebeu mais de $\mathrm{R} \$ 5$ milhões. ${ }^{106}$

A partir de julho de 1998, nove municípios mineiros passam a se beneficiar do ICMS Ecológico, com licença de operação ambiental para sistemas de disposição final de lixo e/ou esgotos sanitários, abrangendo uma população de 3.100 .000 habitantes, sendo que 6 (seis) deles com o retorno do investimento no primeiro ano de operação regular do sistema. ${ }^{107}$

Senise Zeola destaca que:

"Além do benefício ambiental e econômico, outro retorno importante do ICMS Ecológico Marrom, relativo ao saneamento ambiental, foi despertar a atenção dos administradores locais e provocar suas iniciativas em relação à necessidade de investir na implantação e manutenção de sistemas de tratamento.

$\mathrm{Na}$ viabilização dos sistemas de saneamento ambiental, o ICMS Ecológico vem representando, para o administrador municipal, uma nova fonte complementar de recursos, somada às fontes convencionais de financiamento. A receita extra do imposto acima citado contribui para financiar a amortização do investimento e a própria operação do sistema.

Os Municípios que desenvolveram atividades na área ambiental tiveram aumentado em sua receita anual mais de 200\%."

\footnotetext{
${ }^{105}$ CAMPOS, Léo Pompeu de Rezende. ICMS ecológico: experiências nos estados do Paraná, São Paulo, Minas Gerais e alternativas na Amazônia. Disponível em <http:// www.mma.gov.br/port/sds/index.cfm>. Acesso em 11.mai.2005.

${ }^{106}$ Disponível em <http://www.ada.com.br/tvp/noticias/regiao/regiao_2.asp>. Acesso em 31.mar.2005.

${ }^{107}$ CAMPOS, Léo Pompeu de Rezende. ICMS ecológico: experiências nos estados do Paraná, São Paulo, Minas Gerais e alternativas na Amazônia. Disponível em $<$ http:// www.mma.gov.br/port/sds/index.cfm>. Acesso em 11.mai.2005.

${ }^{108}$ ZEOLA, Senise Freire Chacha. ICMS - Instrumento de Proteção e Conservação do Meio Ambiente. Revista de Direito Ambiental. São Paulo, n. 30, p. 179-197.
} 


\section{Conclusão}

A questão ambiental ainda está longe de ser solucionada. Muitos temas ainda não foram sequer ou suficientemente discutidos. Tampouco foram implantadas políticas públicas em quantidade suficiente em face da demanda da proteção do meio ambiente. É preciso buscar o desenvolvimento sustentável, compatibilizando o desenvolvimento econômico com a preservação ambiental.

Enfrentamos atualmente um grande problema, um obstáculo ao desenvolvimento sustentável. Trata-se das externalidades negativas, que são efeitos externos das atividades econômicas, maléficos à sociedade. A redução ou eliminação dessas externalidades negativas, por meio de ações coerentes de políticas públicas, é possível de ser obtida por regras do direito e da economia capazes de determinar o comportamento dos agentes econômicos.

Em se tratando de atividades econômicas, de empreendimentos que produzem lucros privados, é preciso estabelecer mecanismos de internalização dos custos capazes de fazer frente à reparação e à preservação ambiental. A tributação ambiental tem, nesse ponto, importante papel, seja no seu caráter fiscal ou, mais eficientemente, através da extrafiscalidade, com a adoção de incentivos para prevenir danos em potencial.

Nesse contexto, insere-se o ICMS Ecológico, como instrumento financeiro de conservação e preservação do meio ambiente. O conceito trazido pelo ICMS Ecológico é ousado e inovador, porque, ao invés de repressões e punições, cria estímulos e incentivos aos Municípios que zelam pelo meio ambiente, mediante a aplicação dos princípios da prevenção e do protetor recebedor (ou não-poluidor recebedor) e também através da compensação financeira. O ICMS Ecológico tem contribuído para a melhoria da conservação 
do meio ambiente, com resultados positivos em todos os Estados onde foi implementado.

Um aspecto relevante do ICMS Ecológico é o fomento à atuação dos Municípios para a solução de problemas ambientais locais, tais como: ações de preservação da qualidade de unidades de conservação; saneamento básico; manutenção de mananciais de abastecimento público de água; apoio às comunidades indígenas; sistemas de tratamento e disposição final de resíduos sólidos urbanos (lixo); enfim, todas as ações voltadas para a melhoria da qualidade de vida, que promovam o equilíbrio ecológico e o desenvolvimento sustentável. De forma direta ou indireta essas atuações geram rendas e colaboram com o progresso dos Municípios.

Outra questão que deve ser ressaltada é a de que tais repasses financeiros são de extrema relevância, para evitar que aqueles que não se preocupam com a preservação ambiental utilizem-se do argumento de que a falta de "desenvolvimento" de uma certa região é causada pelas restrições ambientais (áreas de preservação ambiental) à instalação de indústrias e loteamentos. Esse argumento, muito disseminado no Brasil, tende a ser utilizado para atribuir a causa da fome e da miséria das populações locais à preocupação com o meio ambiente.

A importância da elaboração deste trabalho reside na escassez de material a respeito deste tema. Embora, como demonstrado, tratem-se de questões de altíssima relevância, a doutrina nacional ainda não as aborda com a merecida atenção. São raríssimos os pesquisadores, como Wilson Loureiro, do Paraná, que se dedicam profundamente ao estudo do ICMS Ecológico. Assim, a base desta pesquisa está na legislação dos Estados brasileiros que criaram, ainda que nem todos tenham implantado, o ICMS Ecológico. 


\section{Referências bibliográficas}

\section{Livros:}

ANTUNES, Paulo de Bessa. Direito Ambiental. Rio de Janeiro: Lúmen Júris, 2000.

ARAÚJO, Cláudia Campos de et al.. Meio Ambiente e Sistema Tributário: Novas Perspectivas. São Paulo: Senac, 2003.

DERANI, Cristiane. Direito Ambiental Econômico. São Paulo: Max Limonad, 1997.

MACHADO, Paulo Affonso Leme. Direito Ambiental Brasileiro. $11^{\text {a }}$ ed. São Paulo: Malheiros, 2003.

MANKIW, N. Gregory. Introdução à Economia: princípios de micro e macroeconomia. 2. ed. Tradução de Maria José Cyhlar Monteiro. Rio de Janeiro: Campus, 2001.

MEIRELLES, Hely Lopes. Direito Administrativo Brasileiro. $24^{\mathrm{a}}$ ed. São Paulo: Malheiros, 1999.

MODÉ, Fernando Magalhães. Tributação Ambiental - a função do tributo na proteção do meio ambiente. Curitiba: Juruá, 2003.

MUKAI, Toshio. Direito Ambiental Sistematizado. $4^{\mathrm{a}}$ ed. Rio de Janeiro: Forense Universitária, 2002. 
NUNES, Cleucio Santos. Direito Tributário e Meio Ambiente. São Paulo: Dialética, 2005.

OLIVEIRA, José Marcos Domingues de. Direito Tributário e Meio Ambiente: Proporcionalidade, Tipicidade Aberta e Afetação da Receita. $2^{\mathrm{a}}$ ed. Rio de Janeiro: Renovar, 1999.

\section{Artigos de Livros e Periódicos:}

ALTAMIRANO, Alejandro C. El Derecho Constitucional a un Medio Ambiente Sano, Derechos Humanos y su Vinculación com el Derecho Tributario. P. 19 - 93. In MARINS, James (coord.). Tributação e Meio Ambiente - Livro 2. Curitiba: Juruá, 2004.

BENJAMIN, Antônio Herman V. Introdução ao Direito Ambiental Brasileiro. p. 11. in SOARES JÚNIOR, Jarbas; GALVÃO, Fernando (coords.). Direito Ambiental na Visão da Magistratura e do Ministério Público. Minas Gerais: Del Rey, 2003.

FAZOLLI, Silvio Alexandre. Princípios Ambientais Tributários e Extrafiscalidade. Revista de Direito Ambiental. São Paulo, n. 34. p. 78-82.

FERRAZ, Roberto. Tributação e Meio Ambiente: o green tax no Brasil (a contribuição de intervenção da Emenda 33/2001). Revista de Direito Ambiental. São Paulo, n 31. p. 167-172.

FIGUEIREDO, Marcelo. Tributação, Ecologia e Meio Ambiente - Mesa de Debates “C”. Revista de Direito Tributário, n 78. p. 69-89. 
GAMA, Guilherme Calmon Nogueira da. Os Privilégios Fiscais: Isenções e Incentivos Fiscais. Revista de Direito Tributário, no 76. p. 215-225.

GUERRA, Sinclair Mallet-Guy; SUAREZ, Miriam Liliana Hinostroza. Questões Econômicas e Implicações Ambientais: Visão Introdutória. Revista de Direito Ambiental. São Paulo, n. 8.

MIRRA, Álvaro Luiz Valery. Princípios Fundamentais do Direito Ambiental. Revista de Direito Ambiental. São Paulo, n. 2. p. 50 - 66.

MOUSINHO, Patrícia. Glossário. p. 333-367. in TRIGUEIRO, André (coord.). Meio Ambiente no Século 21: 21 especialistas falam da questão ambiental nas suas áreas de conhecimento. $2^{\mathrm{a}}$ ed. Rio de Janeiro: Sextante, 2003.

ZEOLA, Senise Freire Chacha. ICMS - Instrumento de Proteção e Conservação do Meio Ambiente. Revista de Direito Ambiental. São Paulo, n. 30, p. 179-197.

\section{Documentos Eletrônicos:}

CAMPOS, Léo Pompeu de Rezende. ICMS ecológico: experiências nos estados do Paraná, São Paulo, Minas Gerais e alternativas na Amazônia. Disponível em <http:// www.mma.gov.br/port/sds/index.cfm>. Acesso em 11.mai.2005.

PIRES, Éderson. Icms ecológico. Aspectos pontuais. Legislação comparada. Jus Navigandi, Teresina, a. 6, n. 52, nov. 2001. Disponível em: $<$ http://www1.jus.com.br/doutrina/texto.asp?id=2328 $>$. Acesso em 31.mar.2005. 
LOUREIRO, Wilson. ICMS Ecológico - A consolidação de uma experiência brasileira de incentivo à conservação da biodiversidade. Disponível em $<$ www.floresta.ufpr.br/pos-

graduacao/seminarios/wilson/ICMS_ecologico_no_brasil.doc $>$. Acesso em 13.abr.2005.

LOUREIRO, Wilson. O ICMS biológico na biodiversidade. Disponível em $<$ http://www.universoverde.com.br/indexa/inicio.htm>. Acesso em 29 mar. 2005 .

LOUREIRO, Wilson. Contribuição do ICMS Ecológico à Conservação da Biodiversidade no Estado do Paraná. Tese de Doutorado apresentada ao Curso de Pós-Graduação em Engenharia Florestal da Universidade Federal do Paraná. Curitiba, 2002. Disponível em <http://pinho.floresta.ufpr.br/posgraduacao/seminarios/wilson/contribuicao_do_icms.pdf $>$. Acesso em 5.mai.2005.

LOUREIRO, Wilson. O ICMS Ecológico na Biodiversidade. Disponível em $<$ http://pinho.floresta.ufpr.br/pos-

graduacao/seminarios/wilson/ICMS_ecologico_no_parana.doc $>$. Acesso em 5.5.2005.

RIBEIRO, Maurício Andrés; LOPES, Ana Lúcia Bahia; e RODRIGUES, Ludmila Alves (da Fundação Estadual do Meio Ambiente de Minas Gerais FEAM) Disponível em $<$ http://www.unilivre.org.br/banco_de_dados/experiencias/experiencias/140.ht ml> Acesso em 30.mar.2005. 
RIBEIRO, Maurício Andrés. O Princípio Protetor-Recebedor para preservar um bem natural. Disponível em: <www.eco21.com.br> Acesso em 10.mai.2005.

\section{Sites da Internet consultados:}

Ambiente Total. Disponível em:

$<$ http://www.ambientetotal.pro.br/icmseco.html+\%22icms + ecol\% $\%$ C3\%B3gico $\% 22+$ paran $\%$ C3\%A1\&hl=pt-BR\&lr=lang pt $>$. Acesso em 30.mar.2005.

Associação Nacional de Pós-Graduação e Pesquisa em Ambiente e Sociedade. Disponível em:

$<$ http://www.anppas.org.br/encontro/segundo/Papers/GT/GT15/ciccarini_nune s.pdf>. Acesso em 31.mar.2005.

Carbono Brasil. Disponível em:

$<$ http://www.carbonobrasil.com/noticias.asp?iNoticia=6542\&iTipo=18\&idiom $\mathrm{a}=1>$. Acesso em 30.mar.2005.

Instituto Ambiental do Paraná - IAP. Disponível em: $<$ http://www.pr.gov.br/meioambiente/iap/bio_icms.shtml $>$. Acesso em 30.mar.2005.

Secretaria de Estado da Receita - Governo do Estado do Rio de Janeiro. Disponível em:

$<$ http://www.receita.rj.gov.br/info/arrecadacao/dados_arrec/icms/comp_anual/ 2004_comp_anual.pdf $>$ Acesso em 10.mai.2005. 
Secretaria do Planejamento e Meio Ambiente do Estado do Tocantins.

Disponível em: <http://www.seplan.to.gov.br/dma/icms/Anexo_Lei1323.pdf $>$. Acesso em 01.abr.2005.

World Wildlife Fund (WWF) - Brasil. Disponível em:

$<$ http://www.wwf.org.br/projetos/projeto.asp?lista=bioma\&item=19\&item=73

\&imagem=../bioma/int_nacional $>$ Acesso em 05.mai.2005. 